\title{
Saline and alkaline stresses alter soil properties and composition and structure of gene-based nitrifier and denitrifier communities in a calcareous desert soil
}

\author{
Jiaxin Guo, Yongxue Zhou, Huijuan Guo and Wei Min ${ }^{*}$
}

\begin{abstract}
Background: Saline and alkaline stresses damages the health of soil systems. Meanwhile, little is known about how saline or alkaline stress affects soil nitrifier and denitrifier communities. Therefore, we compared the responses of gene-based nitrifier and denitrifier communities to chloride (CS), sulfate (SS), and alkaline (AS) stresses with those in a no-stress control (CK) in pots with a calcareous desert soil.

Results: Compared with $\mathrm{CK}$, saline and alkaline stress decreased potential nitrification rate (PNR) and $\mathrm{NO}_{3}-\mathrm{N}$; increased $\mathrm{pH}$, salinity, water content, and $\mathrm{NH}_{4}-\mathrm{N}$; and decreased copy numbers of amoA-AOA and amoA-AOB genes but increased those of denitrifier nirS and nosZ genes. Copies of nirK increased in SS and AS but decreased in CS. There were more copies of amoA-AOB than of amoA-AOA and of nirS than of nirk or nosZ. Compared with CK, SS and AS decreased operational taxonomic units (OTUs) of amoA-AOB but increased those of nirS and nosZ, whereas CS decreased nirk OTUs but increased those of nosZ. The numbers of OTUs and amOA-AOB genes were greater than those of amoA-AOA. There were positive linear relations between PNR and amoA-AOA and amoA-AOB copies. Compared with CK, the Chao 1 index of amoA-AOA and amoA-AOB decreased in AS, that of nirk increased in CS and $S S$, but that of nirS and nosZ increased in all treatments. The Shannon index of amoA-AOB decreased but that of nirS increased in CS and SS, whereas the index of nirk decreased in all treatments. Saline and alkaline stress greatly affected the structure of nitrifier and denitrifier communities and decreased potential biomarkers of nirstype; however, AS increased those of nirk- and nosZ-type, and SS decreased those of nosZ-type. Soil water content, $\mathrm{pH}$, and salinity were important in shaping amoA-AOA and denitrifier communities, whereas soil water and $\mathrm{pH}$ were important to amoA-AOB communities.
\end{abstract}

Conclusion: These results indicate that the nitrifier and denitrifier communities respond to saline and alkaline stresses conditions. Communities of amoA-AOA and amoA-AOB contribute to nitrification in alluvial gray desert soil, and those of nirs are more important in denitrification than those of nirk or nosZ.

Keywords: Chloride stress, Sulfate stress, Alkaline stresses, Bacterial community diversity, High-throughput sequencing, Potential nitrification rate

\footnotetext{
*Correspondence: minwei555@126.com

Department of Resources and Environmental Science, Agriculture College, Shihezi University, Box \#425, Shihezi, Xinjiang 832003, People's Republic of China
}

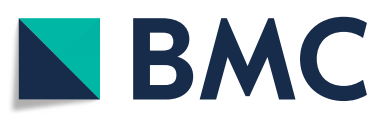

(c) The Author(s). 2021 Open Access This article is licensed under a Creative Commons Attribution 4.0 International License, which permits use, sharing, adaptation, distribution and reproduction in any medium or format, as long as you give appropriate credit to the original author(s) and the source, provide a link to the Creative Commons licence, and indicate if changes were made. The images or other third party material in this article are included in the article's Creative Commons licence, unless indicated otherwise in a credit line to the material. If material is not included in the article's Creative Commons licence and your intended use is not permitted by statutory regulation or exceeds the permitted use, you will need to obtain permission directly from the copyright holder. To view a copy of this licence, visit http://creativecommons.org/licenses/by/4.0/ The Creative Commons Public Domain Dedication waiver (http://creativecommons.org/publicdomain/zero/1.0/) applies to the data made available in this article, unless otherwise stated in a credit line to the data. 


\section{Background}

Salt stress is a primary threat to environmental resources and human health and also decreases crop yields and restricts the use of agricultural land [1]. Estimates suggest there are 1128 Mha of salt-affected land worldwide [2], accounting for more than $20 \%$ of total cultivated and $33 \%$ of irrigated agricultural lands [3]. In China, there are approximately $8.11 \times 10^{7}$ ha of saline or alkaline soils, accounting for 8 to $9 \%$ of the total land area [4]. In general, salt-affected soils are either saline or alkaline. Alkaline salt stress and neutral salt stress are different and therefore should be correctly distinguished as alkaline stress and saline stress, respectively [5]. The effects of saline stress $\left(\mathrm{NaCl}\right.$ or $\left.\mathrm{Na}_{2} \mathrm{SO}_{4}\right)$ are generally osmotic and ionic, whereas alkaline stress $\left(\mathrm{NaHCO}_{3}\right.$ or $\left.\mathrm{Na}_{2} \mathrm{CO}_{3}\right)$ results from higher $\mathrm{pH}$. Saline or alkaline stress adversely affects soil physicochemical properties, soil microbiological processes, and plant growth [6, 7].

Nitrification is the oxidation of ammonium $\left(\mathrm{NH}_{4}{ }^{+}\right)$to nitrite $\left(\mathrm{NO}_{2}{ }^{-}\right)$and then to nitrate $\left(\mathrm{NO}_{3}{ }^{-}\right)$. The nitrification process primarily involves ammonia-oxidizing bacteria $(\mathrm{AOB})$ or archaea (AOA) and nitrite-oxidizing bacteria; ammonia oxidation is the rate-limiting step in nitrification and is driven by AOA and AOB. Denitrification is the stepwise reduction of $\mathrm{NO}_{3}{ }^{-}$and $\mathrm{NO}_{2}{ }^{-}$to the gases nitric oxide (NO), nitrous oxide $\left(\mathrm{N}_{2} \mathrm{O}\right)$, and nitrogen $\left(\mathrm{N}_{2}\right)$ under the catalysis of enzymes [8]. The reduction of $\mathrm{NO}_{2}{ }^{-}$to $\mathrm{NO}$ is the rate-limiting step in denitrification. Nitrification and denitrification may occur simultaneously in different microsites of the same soil, and are affected by changes in salinity, $\mathrm{pH}$, mineral $\mathrm{N}$, soil water content (SWC), and temperature [9-13]. Soil salinity and $\mathrm{pH}$ affects nitrification and denitrification, primarily by inhibiting the activity of nitrifying and denitrifying bacteria. However, the response of $\mathrm{N}$ microbes to alkalinity or salinity stress is indeterminate.

Both $\mathrm{AOA}$ and $\mathrm{AOB}$ have $a m o A$ genes that encode ammonia monooxygenase to oxidize $\mathrm{NH}_{4}-\mathrm{N}$. Ammonia oxidation is dominated by AOA in acidic environment or low nutrient content environment but by $\mathrm{AOB}$ in alkaline soils, because of the low survival of AOB at low $\mathrm{pH}$ [14-17]. Shi et al. found that AOB copies were positively correlated with soil water content, $\mathrm{NH}_{4}-\mathrm{N}$, and $\mathrm{NO}_{3}-\mathrm{N}$ and negatively correlated to soil $\mathrm{pH}$, indicating that $\mathrm{AOB}$ was mainly affected by soil water content, $\mathrm{pH}, \mathrm{NH}_{4}-\mathrm{N}$, and $\mathrm{NO}_{3}-\mathrm{N}$ [18]. In addition, previous studies found that copies of the amo $A$ gene of $\mathrm{AOB}$ and AOA are negatively correlated with soil salinity $[19,20]$. However, according to Wang and $\mathrm{Gu}$, high soil salinity can promote the growth of $\mathrm{AOB}$ and AOA [21], and Mosier and Francis found that copies of $a m o A$ of $\mathrm{AOB}$ increase with an increase in soil salinity [22]. Therefore, how soil salinity affects the relative contributions of $\mathrm{AOB}$ and $\mathrm{AOA}$ to nitrification remains debatable. There is also little information on how $\mathrm{pH}$ and salinity affect the distributions of AOA and AOB in saline or alkaline soils.

The genes nirK, nirS, and nos $Z$ are frequently used as functional markers to analyze denitrifier communities [23]. Soil salinity inhibits nitrification and denitrification rates $[24,25]$. However, denitrifier communities respond differently to diverse environments. Salinity reduces copies of the denitrifier genes nirK, nirS, and nos $Z$ and alters denitrifier community structure [26-28]. By contrast, Franklin et al. and $\mathrm{Li}$ et al. found that gene copies of denitrifying bacteria increased along gradients of increasing salinity $[29,30]$. Thus, the effects of salinity on the abundance of soil denitrifying bacteria also remain unclear. Additionally, a pH-dependent mechanism is involved in regulating soil microbial community composition and function [31]. For example, Bai et al. found that increases in $\mathrm{pH}$ in saline soil increase the activity of denitrifying microorganisms [32]. These studies demonstrate that, owing to the complexity of soil microbial communities, the effects of saline or alkaline stress on the abundance and structure of nitrifier and denitrifier communities are poorly understood.

Nitrogen $(\mathrm{N})$ is an essential nutrient needed to improve crop yields, and many farmers apply excess $\mathrm{N}$ fertilizer to ensure maximum yield and profit [33]. Soil microbial communities have essential roles in nutrient cycling, and many of the microbiological processes involved in $\mathrm{N}$ cycling in terrestrial ecosystems are altered under saline or alkaline stress, which can affect plant productivity and production of atmospherically active gases. An understanding of the effects of saline and alkaline stresses on the abundance of nitrifiers and denitrifiers is important, because nitrification and denitrification rates determine soil inorganic $\mathrm{N}$ concentrations, nitrate leaching, and the production of $\mathrm{N}_{2} \mathrm{O}[20,27,34]$. An increase in soil salinity may shift microbial community structure and increase the predominance of saline or alkaline adapted microorganisms. However, there are few reports focused on the effects of saline and alkaline stresses on composition and structure of gene-based nitrifier and denitrifier communities, and the results will help to guide the application of saline and alkaline soil.

In this study, the effects of saline and alkaline stresses on nitrifier and denitrifier abundance and community structure were determined. We hypothesized that (i) saline and alkaline stresses would have different effects on nitrifier and denitrifier abundance, but overall, an increase in soil salinity or alkalinity would decrease the abundance of both, and that (ii) saline and alkaline stresses would have different effects on nitrifier and denitrifier community structure, but with an increase in salinity or alkalinity, the predominance of saline or alkaline-adapted microorganisms would increase. The 
hypotheses were tested in a pot experiment with cotton plants and different types of soil salinity and alkalinity stresses. We assessed nitrifier and denitrifier abundance by quantitative polymerase chain reaction (q-PCR) and community structure by $16 \mathrm{~S}$ rRNA gene sequencing. The information obtained in this study can provide a theoretical basis for the efficient use of $\mathrm{N}$ fertilizers and rational $\mathrm{N}$ management in saline or alkaline soils in arid areas.

\section{Results}

\section{Cotton biomass}

Cotton biomass decreased significantly under salt-alkali stress (Table 1). Compared with the CK, the biomass of the leaves, stem, and root was significantly lower by $47.55,65.68$, and $32.26 \%$, respectively, in the CS treatment, by $46.85,50.89$, and $43.01 \%$, respectively, in the SS treatment, and by $60.14,57.40$, and $31.18 \%$, respectively, in the AS treatment. Overall, compared with the CK, total cotton biomass was decreased by $51.94,47.74$, and $53.18 \%$ in the CS, SS, and AS treatment, respectively.

\section{Soil physicochemical properties and potential nitrification} rate

Saline and alkaline stresses significantly increased SWC (Fig. 1a) and salinity (Fig. 1b). Across all treatments, including CK, SWC was between 11.88 and $18.87 \%$, and salinity was between 0.33 and $2.64 \mathrm{dS} \mathrm{m} \mathrm{m}^{-1}$. Compared with CK, SWC was $44.59 \%$ higher in CS, $58.82 \%$ higher in SS, and $18.05 \%$ higher in AS, and salinity was $438.41 \%$ higher in CS 708.99\% higher in SS, and 83.25\% higher in AS. Compared with that in CK, Saline and alkaline stresses significantly increased soil pH (Fig. 1c). In CS and $\mathrm{SS}$, the $\mathrm{pH}$ increased by 0.69 and 0.63 units, respectively, compared with that in CK. In AS, the $\mathrm{pH}$ was significantly higher than that in the other treatments and was approximately 2.00 units higher than that in CK. The $\mathrm{NH}_{4}-\mathrm{N}$ content increased significantly in CS, SS, and AS, compared with that in CK (Fig. 1d), increasing by $106.29 \%$ in CS, $173.54 \%$ in SS, and $236.74 \%$ in AS. By

Table 1 Component biomass and total biomass of cotton plants as affected by salt and alkali stresses in a calcareous desert soil

\begin{tabular}{lllll}
\hline Treatments & \multicolumn{5}{l}{ Biomass (g/plant) } \\
\cline { 2 - 5 } & Leaves & Stems & roots & Total \\
\hline CK & $7.15 \mathrm{a}$ & $7.61 \mathrm{a}$ & $3.72 \mathrm{a}$ & $18.48 \mathrm{a}$ \\
CS & $3.75 \mathrm{~b}$ & $2.61 \mathrm{~d}$ & $2.52 \mathrm{~b}$ & $8.88 \mathrm{C}$ \\
SS & $3.80 \mathrm{~b}$ & $3.74 \mathrm{~b}$ & $2.12 \mathrm{C}$ & $9.66 \mathrm{~b}$ \\
AS & $2.85 \mathrm{c}$ & $3.24 \mathrm{c}$ & $2.56 \mathrm{~b}$ & $8.65 \mathrm{c}$
\end{tabular}

$\mathrm{CK}$, control treatment without salt or alkali stress; $\mathrm{CS}, \mathrm{NaCl}$ stress treatment; $\mathrm{SS}$, $\mathrm{Na}_{2} \mathrm{SO}_{4}$ stress treatment; and $\mathrm{AS}, \mathrm{Na}_{2} \mathrm{CO}_{3}+\mathrm{NaHCO}_{3}$ stress treatment. Different lowercase letters in the same column indicate significant differences among treatments $(P<0.05)$ contrast, the $\mathrm{NO}_{3}-\mathrm{N}$ content decreased significantly in CS, SS, and AS, compared with that CK, decreasing by $7.68 \%$ in CS, $10.68 \%$ in SS, and $13.47 \%$ in AS (Fig. 1e). Similarly, the soil PNR decreased significantly in CS, SS, and AS, compared with that in CK (Fig. 1f), decreasing by $501 \%$ in CS, $608 \%$ in SS, and $697 \%$ in AS. There were no significant differences in PNR among CS, SS, and AS.

\section{amoA-AOA, amoA-AOB, nirK, nirS, and nosZ gene copy numbers}

Saline and alkaline stresses significantly decreased amoA-AOA (Fig. 2a) and amoA-AOB (Fig. 2b) gene copy numbers. Across all treatments, including $C K$, gene copy numbers of amoA-AOA were between $0.44 \times 10^{6}$ and $1.48 \times 10^{6}$ per $g$ dry soil and those of $a m o A-A O B$ were between $3.89 \times 10^{7}$ and $5.45 \times 10^{7}$ per $g$ dry soil. Thus, the gene copy numbers of $a m o A-A O B$ were higher than those of amoA-AOA. The amoA-AOA and amoA-AOB gene copies in CS, SS, and AS were significantly lower than those in CK. For amoA-AOA gene copies, the number was not significantly different between CS and AS. For amoA-AOB gene copies, the number was not significantly different between CS and SS. Compared with CK, amoA-AOA gene copies were 75.18\% lower in CS, 63.34\% lower in SS, and70.08\% lower in AS. Compared with CK, amoA-AOB gene copies were $17.48 \%$ lower in CS, $10.87 \%$ lower in SS, and $28.46 \%$ lower in AS. The amoA-AOA/amoA-AOB ratio in CS, SS, and AS was significantly lower than that in CK (Fig. 2c), but there was no significant difference between SS and AS.

Figure $2 \mathrm{~d}$, e, and $\mathrm{f}$ show the copy numbers of the denitrification genes nirK, nirS, and nos $Z$, respectively. Across all treatments, including $\mathrm{CK}$, the numbers of nirK were between $0.74 \times 10^{7}$ and $1.65 \times 10^{7}$ per g dry soil, those of nirS between $4.69 \times 10^{7}$ and $33.34 \times 10^{8}$ per g dry soil, and those of nos $Z$ between $2.23 \times 10^{7}$ and $7.49 \times 10^{7}$ per $g$ dry soil. Compared with CK, the nirK copies decreased in CS by $41.54 \%$ but increased significantly by $28.94 \%$ in SS and by $14.71 \%$ in AS. Saline and alkaline stresses significantly increased nirS and nos $Z$ gene copy numbers, compared with those in CK. The nirS copy numbers increased by $201.51 \%$ in CS, $368.18 \%$ in SS, and $612.57 \%$ in AS. The nos $Z$ copy numbers increased by $46.44 \%$ in CS, $235.86 \%$ in SS, and $78.28 \%$ in AS.

\section{Relations between potential nitrification rate and abundances of $a m O A-A O A$ and $a m O A-A O B$}

Regression analysis showed soil PNR was significantly positively related to the gene copy numbers of both amoA-AOA $\left(R^{2}=0.9122, P<0.001\right.$; Fig. $\left.3 \mathrm{a}\right)$ and $a m o A$ $\mathrm{AOB}\left(R^{2}=0.5533, P=0.005\right.$; Fig. $\left.3 \mathrm{~b}\right)$. Thus, the PNR was highly linearly related to the abundances of amoAAOA and amoA-AOB. 


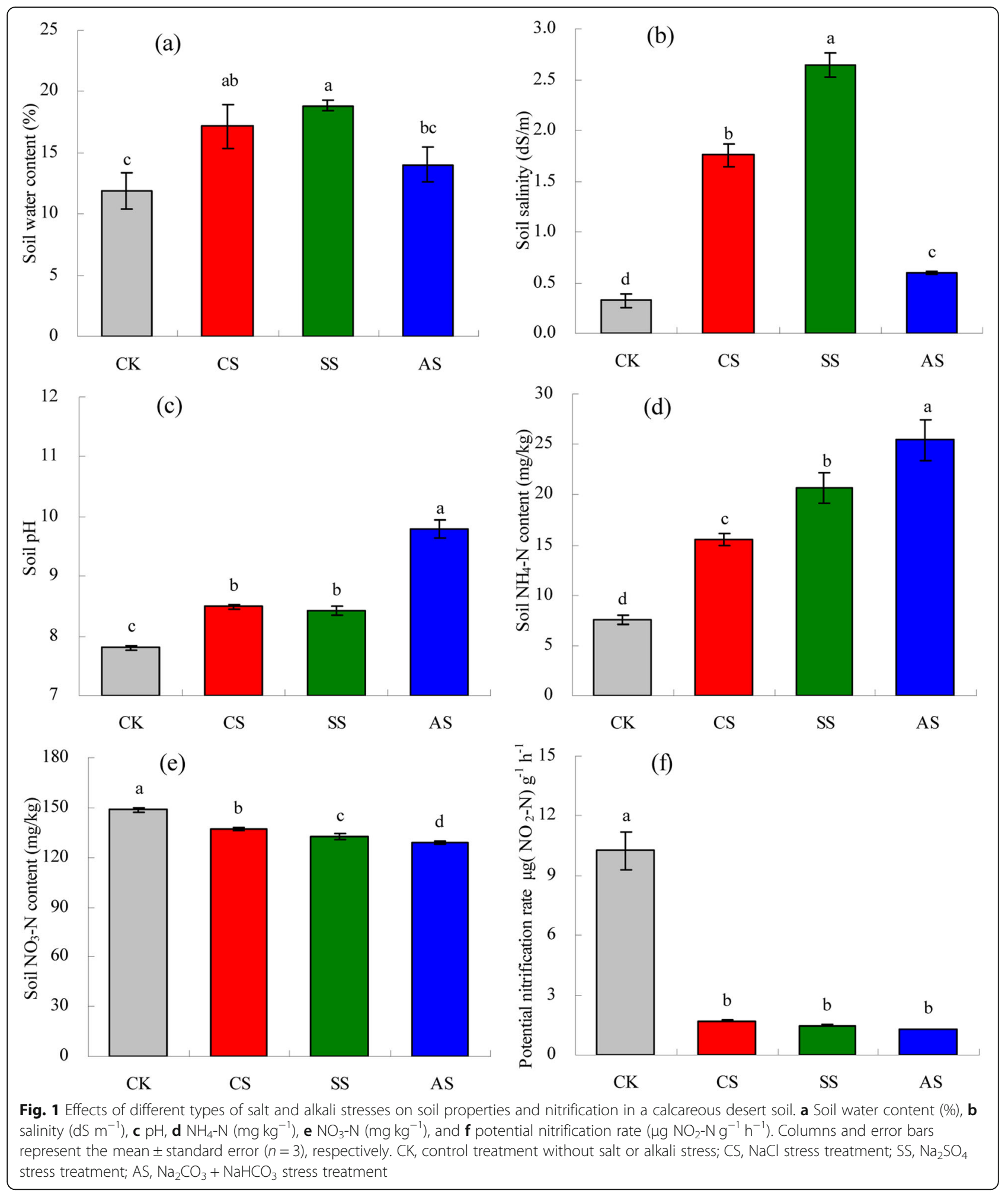

\section{Correlations between soil properties and potential} nitrification rate and abundances of $a m o A-A O A$, amoA$A O B$, nirk, nirS, and nosZ genes

Looking first at the relationships between the soil's physicochemical properties and its PNR and nitrifier communities gene abundances (Table 2). The soil PNR was significantly negatively correlated with $\mathrm{SWC}, \mathrm{EC}_{1: 5}$, $\mathrm{pH}$, and $\mathrm{NH}_{4}-\mathrm{N}$ content, the abundance of amoA-AOA was significantly negatively correlated with SWC, $\mathrm{pH}$, and $\mathrm{NH}_{4}-\mathrm{N}$ content, and the abundance of amoA-AOB 

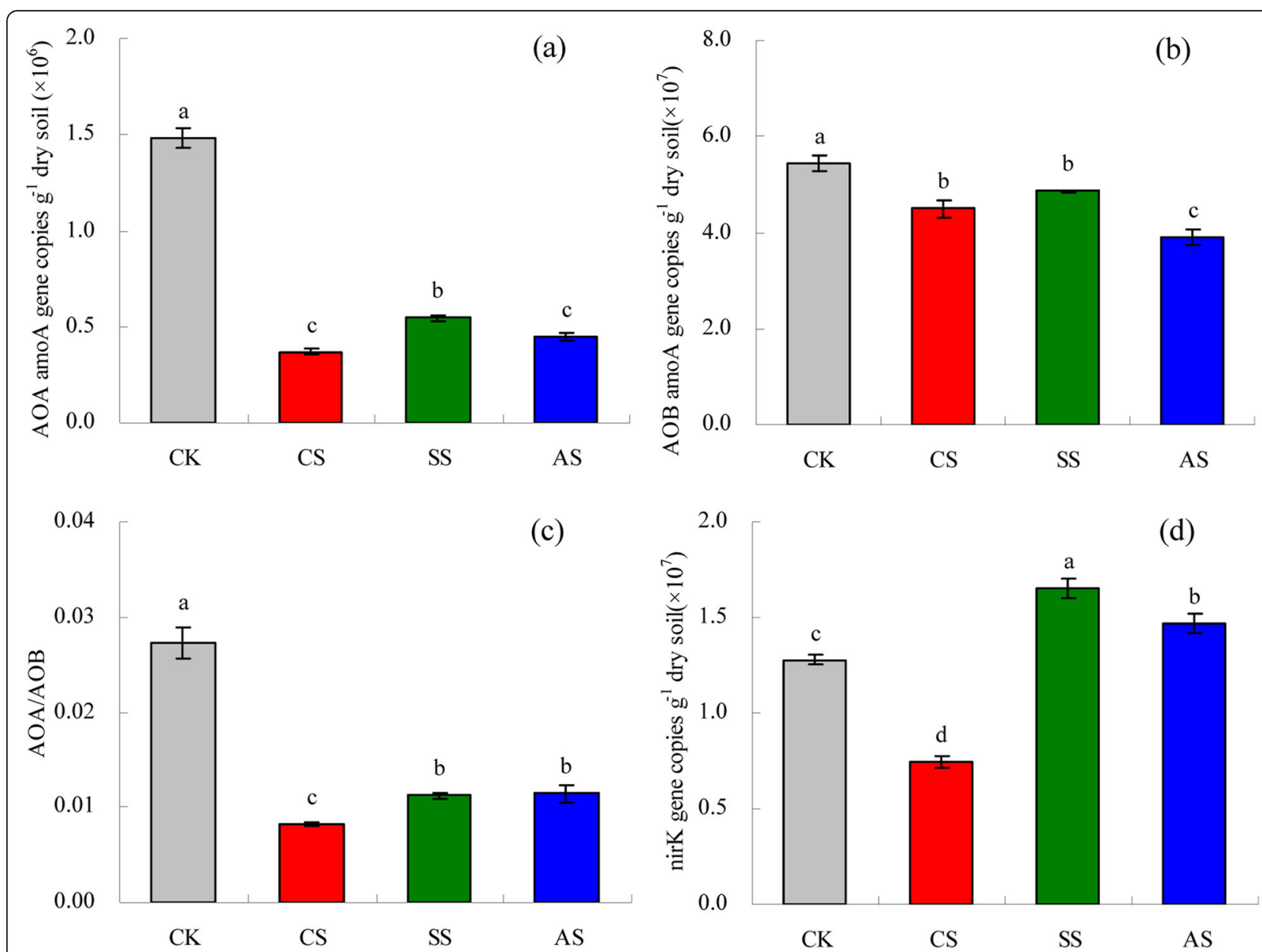

2.0

(d)
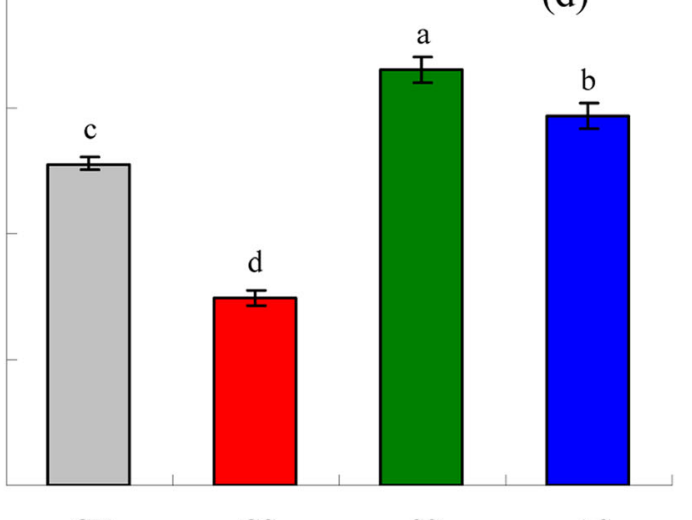

CK

CS

SS

AS
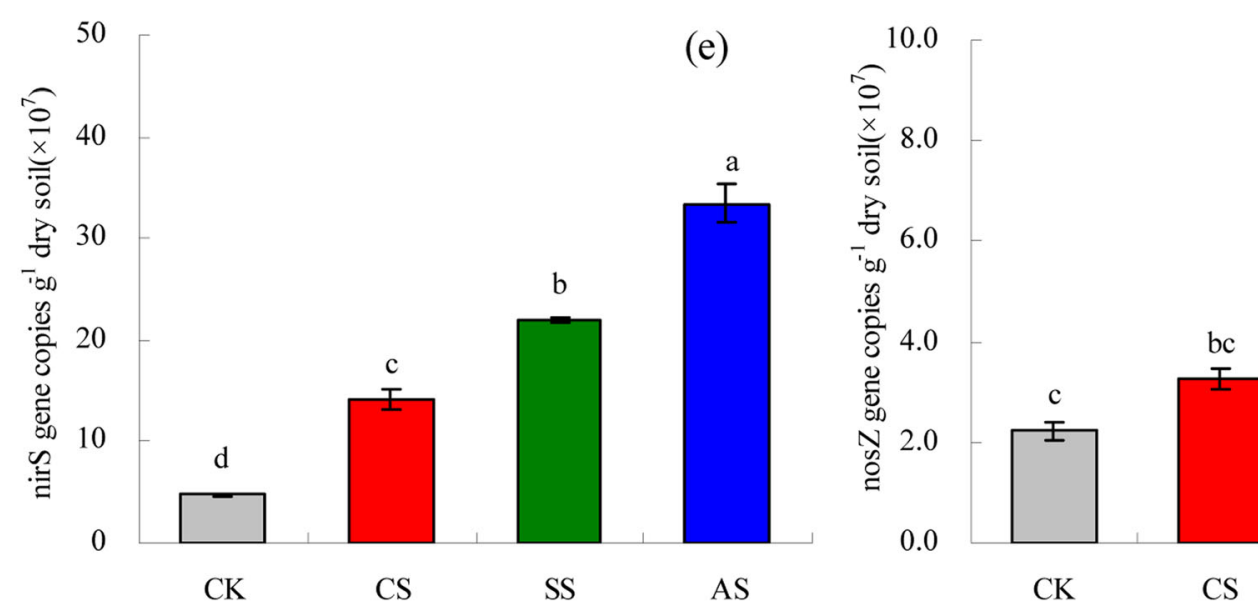

(f)

a

Fig. 2 Effects of different types of salt and alkali stresses on gene copy numbers (no. $\mathrm{g}^{-1}$ dry soil $\left(\times 10^{6}\right.$ or $\left.10^{7}\right)$ ) of different soil bacterial communities involved in nitrification and denitrification in a calcareous desert soil. a amoA-AOA, b amoA-AOB, c amoA-AOA/amoA-AOB ratio, $\mathbf{d}$ nirk, e nirS, and $\mathbf{f}$ nosZ.. Columns and error bars represent the mean \pm standard error $(n=3)$, respectively. CK, control treatment without salt or alkali stress; $\mathrm{CS}, \mathrm{NaCl}$ stress treatment; $\mathrm{SS}, \mathrm{Na}_{2} \mathrm{SO}_{4}$ stress treatment; $\mathrm{AS}, \mathrm{Na}_{2} \mathrm{CO}_{3}+\mathrm{NaHCO}_{3}$ stress treatment

was significant negatively correlated with $\mathrm{pH}$ and $\mathrm{NH}_{4}$ $\mathrm{N}$ content. However, soil PNR and the abundance of amoA-AOA and $a m o A-\mathrm{AOB}$ were significantly positively correlated with soil $\mathrm{NO}_{3}-\mathrm{N}$ content.
Looking at the relationship between the soil's physicochemical properties and denitrifier communities gene abundances, The abundance of nirS was significantly positively correlated with soil $\mathrm{pH}$ and soil $\mathrm{NH}_{4}-\mathrm{N}$ 

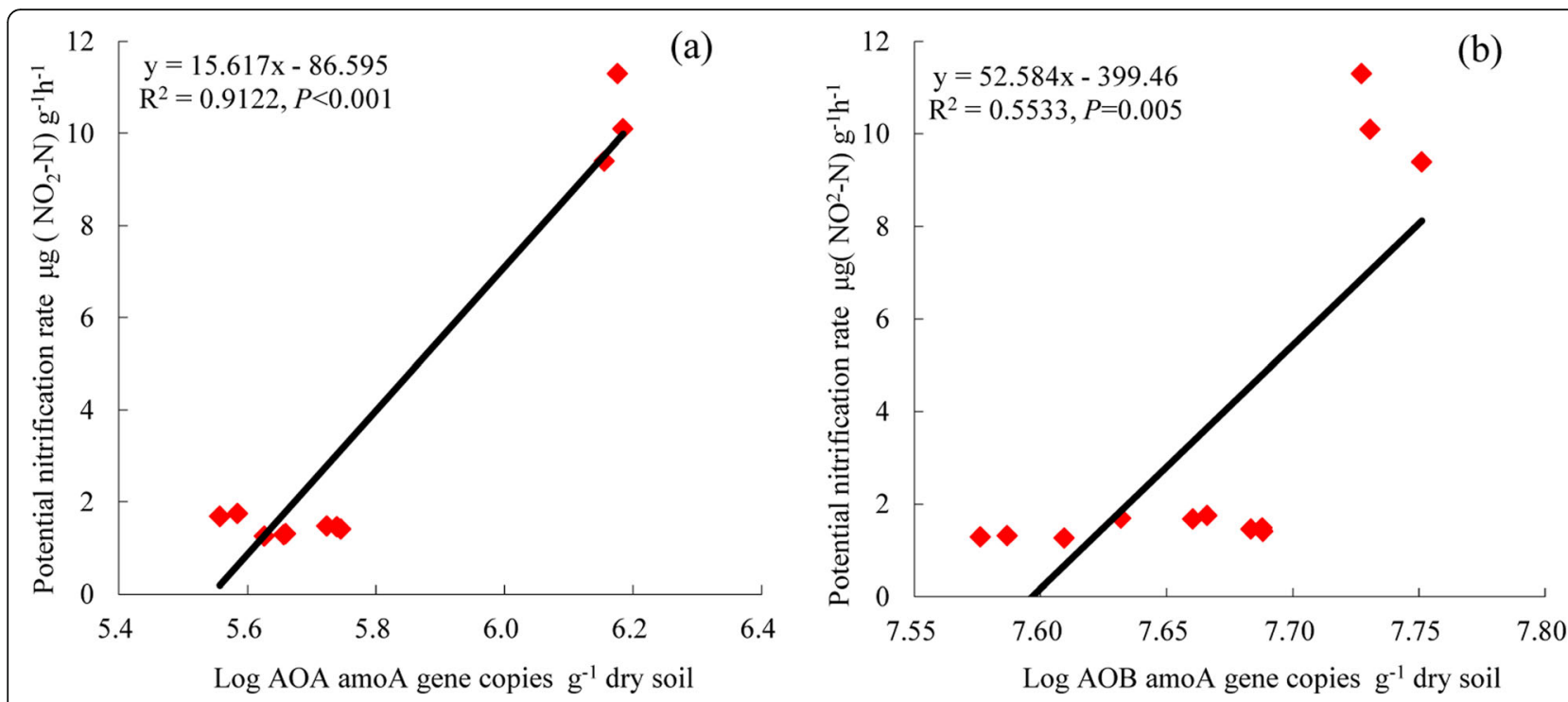

Fig. 3 Regressions of the relations between potential nitrification rate $\left(\mu \mathrm{NO}_{2}-\mathrm{N} \mathrm{g}^{-1} \mathrm{~h}^{-1}\right.$ ) and gene copy numbers (log no. $\mathrm{g}^{-1} \mathrm{dry}$ soil) of a amoA-AOA communities and $\mathbf{b}$ amoA-AOB communities in a calcareous desert soil

content, and the abundance of nos $Z$ was significantly positively correlated with $\mathrm{SWC}$ and $\mathrm{EC}_{1: 5}$, but the abundance of nirS and nos $Z$ was significantly negatively correlated with soil $\mathrm{NO}_{3}-\mathrm{N}$ content. In addition, the abundance of nirK was not significantly correlated with any soil property.

\section{Venn diagrams of the operational taxonomic units of} amoA-AOA, amoA-AOB, nirk, nirS, and nos $Z$ genes

The sequence coverage of amoA-AOA, amoA-AOB, nirK, nirS, and nosZ genes was greater than $99 \%$ in all samples, indicating that the depth reasonably represented the actual communities (Table 3). Saline and alkaline stresses significantly affected the number of OTUs and sequences. For amoA-AOB, the number of OTUs decreased significantly in SS and AS, compared with that in CK. For nirK, the number of OTUs

Table 2 Pearson coefficients of correlation between soil properties and copy numbers of the genes amoA-AOA, amoA$\mathrm{AOB}$, nirK, nirS, and nos $Z$ in a calcareous desert soil

\begin{tabular}{lllllll}
\hline Item & PNR & amoA-AOA & amoA-AOB & nirk & nirS & nosZ \\
\hline $\mathrm{SWC}$ & $-0.675^{\mathrm{a}}$ & $-0.658^{\mathrm{a}}$ & -0.179 & 0.026 & 0.250 & $0.712^{\mathrm{b}}$ \\
$\mathrm{EC}_{1: 5}$ & $-0.604^{\mathrm{a}}$ & -0.563 & -0.015 & 0.094 & 0.142 & $0.813^{\mathrm{b}}$ \\
$\mathrm{pH}$ & $-0.673^{\mathrm{a}}$ & $-0.662^{\mathrm{a}}$ & $-0.918^{\mathrm{b}}$ & 0.220 & $0.935^{\mathrm{b}}$ & 0.136 \\
$\mathrm{NH}_{4} \mathrm{-N}$ & $-0.857^{\mathrm{b}}$ & $-0.798^{\mathrm{b}}$ & $-0.848^{\mathrm{b}}$ & 0.409 & $0.965^{\mathrm{b}}$ & 0.571 \\
$\mathrm{NO}_{3} \mathrm{~N}$ & $0.914^{\mathrm{b}}$ & $0.869^{\mathrm{b}}$ & $0.856^{\mathrm{b}}$ & -0.319 & $-0.942^{\mathrm{b}}$ & $-0.587^{\mathrm{a}}$
\end{tabular}

$E C_{1: 5}$ electrical conductivity, SWC soil water content, PNR potential nitrification rate

${ }^{\mathrm{a}}$ and ${ }^{\mathrm{b}}$ indicate significant correlations at the 0.05 and 0.01 levels (two-tailed), respectively decreased significantly in CS and SS, compared with that in CK. However, for nirS, the number of OTUs increased significantly in SS and AS, compared with that in $\mathrm{CK}$ and for nos $Z$, the number increased significantly in CS, SS, and AS. In addition, For amoA-AOB, the number of sequences decreased significantly in CS, compared with that in CK, however, the number of sequences increased significantly in AS. For nirK, the number of sequences increased significantly in CS, compared with that in CK. For nosZ, the number of sequences increased significantly in CS, SS, and AS, compared with that in CK.

Venn diagrams were used to compare the shared and unique OTUs among amoA-AOA, amoA-AOB, nirK, nirS, and nosZ communities (Fig. 4). One hundred and seventeen amoA-AOA-related OTUs were identified in all treatments, and 19 were shared among the four treatments (16.24\% of the total) (Fig. 4a). Nine hundred and thirty-four amoA-AOB-related OTUs were identified in all treatments, and 106 were shared among the four treatments (11.35\% of the total) (Fig. 4b). The number of amoA-AOB species was significantly greater than that of amoA-AOA species. Furthermore, the saline and alkaline stresses had greater influence on the number of $a m o A$ AOB-related OTUs than on the number of amoA-AOArelated ones.

As shown in Fig. 4c, 1,404 nirK-related OTUs were identified in all treatments, with 150 shared among the four treatments $(10.68 \%$ of the total). As shown in Fig. 4d, 1,026 nirS-related OTUs were identified in all treatments, with 173 shared among the four treatments $(16.86 \%$ of the total). As shown in Fig. 4e, 965 nosZ-related OTUs were identified in all treatments, 


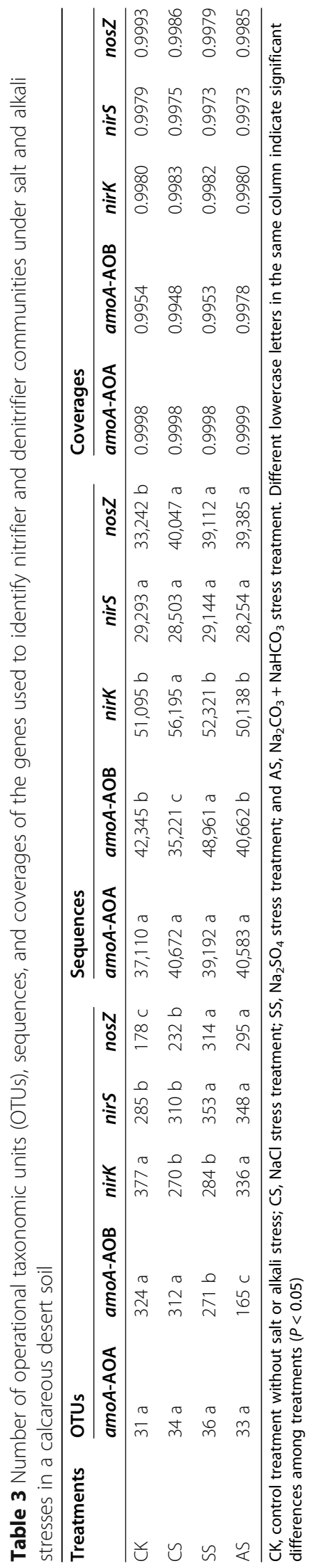


(a)

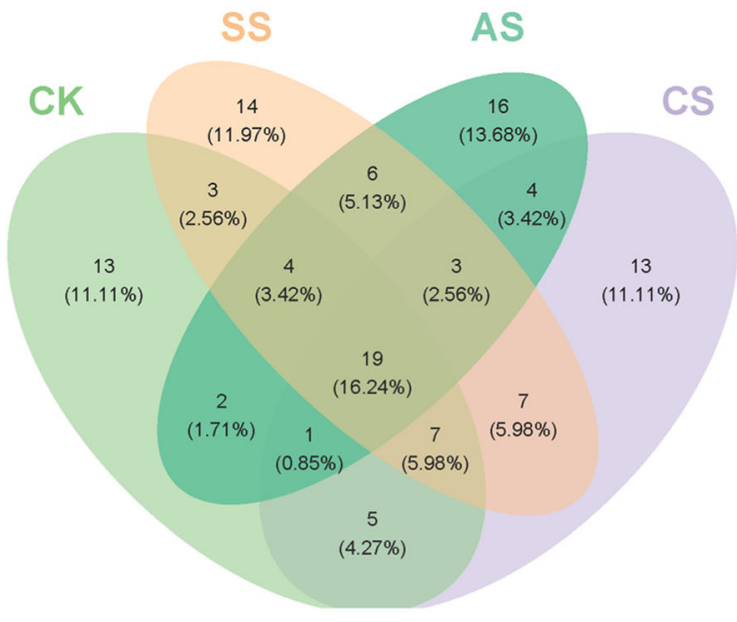

(c)

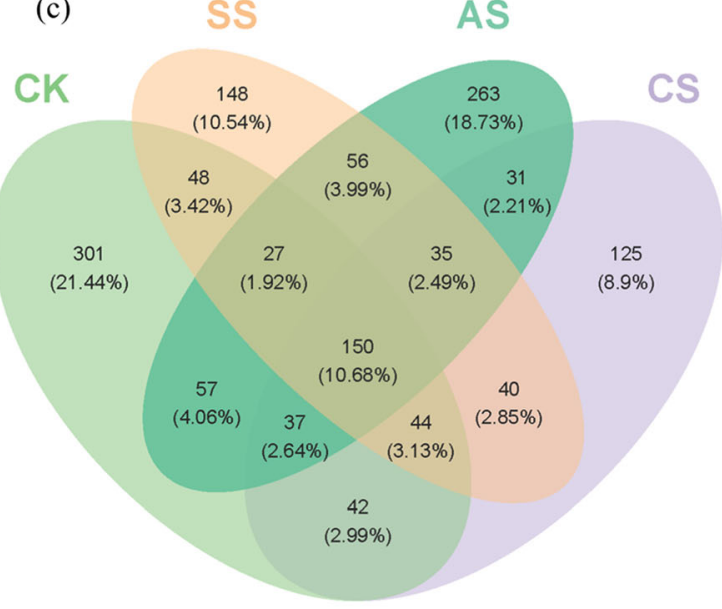

(e)

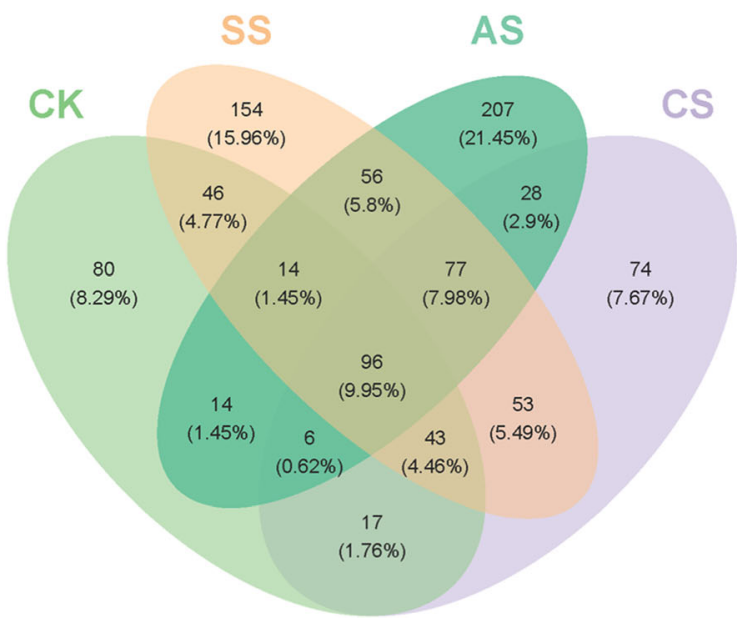

(b)

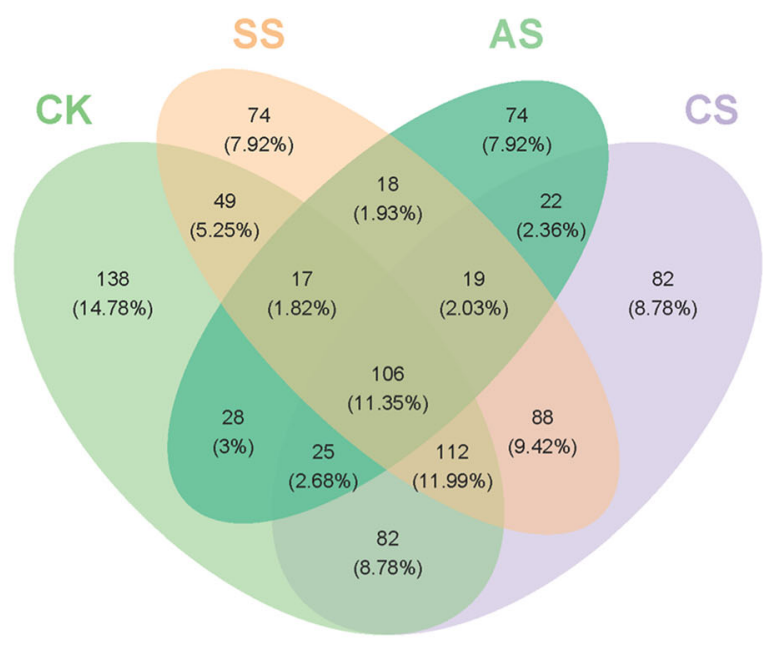

(d)

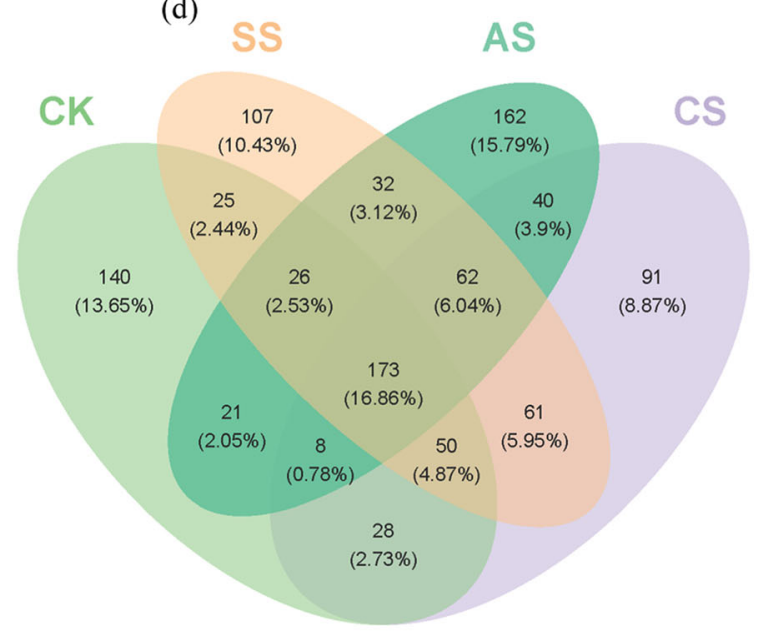

Fig. 4 Venn diagrams based on operational taxonomic units of different communities under different salt and alkali stresses in a calcareous desert soil. The communities were a amoA-AOA, b amoA-AOB, c nirk, d nirS, and e nosZ. CK, control treatment without salt or alkali stress; CS, $\mathrm{NaCl}$ stress treatment; $\mathrm{SS}, \mathrm{Na}_{2} \mathrm{SO}_{4}$ stress treatment; $\mathrm{AS}, \mathrm{Na}_{2} \mathrm{CO}_{3}+\mathrm{NaHCO}_{3}$ stress treatment 
with 96 shared among the four treatments $(9.95 \%$ of the total). The numbers of nirK and nirS species were significantly than that of nos $Z$ species. Furthermore, the saline and alkaline stresses had greater influence on the numbers of nirK- and nirS-related OTUs than on the numbers of nosZ-related ones.

\section{a-Diversity of amoA-AOA, amoA-AOB, nirK-, nirs-, and} nosZ-type denitrifier communities

Table 4 shows the Chao 1 and Shannon diversity indices of amoA-AOA, amoA-AOB, nirK-, nirS-, and nosZ-type denitrifier communities. Compared with $\mathrm{CK}, \mathrm{CS}$ and SS had no effect on the Chao 1 index of $a m o A-A O A$ and amoA-AOB communities; however, AS significantly decreased the Chao 1 index of amoA-AOA and $a m o A$ AOB communities. Compared with CK, CS significantly decreased the Shannon index of amoA-AOA and amoA$\mathrm{AOB}$ communities. In SS the Shannon index of the amoA-AOB community decreased significantly.

Compared with CK, CS and SS significantly decreased the Chaol index of the nirK community, whereas the same treatments significantly increased the index of the nirS and nos $Z$ communities. In addition, the Shannon index of the nirK community decreased significantly in CS and SS, but in those same treatments, the index of the nirS community increased significantly. The Shannon index of the nosZ-type denitrifier community was not affected by any treatment.

\section{Nonmetric multidimensional scaling analysis}

Nonmetric multidimensional scaling analysis was performed to compare the differences in structure of amoA-AOA, amoA-AOB, nirK, nirS, and nosZ communities among treatments (Fig. 5). The amoA-AOA, amoA-AOB, nirK, and nos $Z$ communities were clustered into four groups (Fig. 5a, b, c, d). The structure of nos $Z$ communities was not significant between CS and SS (Fig. 5e). However, the structure of the nos $Z$ communities under saline and alkaline stresses was significantly different from that of those communities in CK. This result indicated that microbial community structure might be directly correlated with soil properties affected by saline and alkaline stresses.

\section{Composition of amoA-AOA, amoA-AOB, nirk-, nirS-, and nosZ-type denitrifier communities}

Saline and alkaline stresses significantly affected the genus-level composition of $a m o A-\mathrm{AOA}$ and $a m o A-\mathrm{AOB}$ communities (Fig. 6). In the amoA-AOA community, the two dominant genera were Nitrososphaera and Candidatus Nitrosocosmicus (Fig. 6a). In all treatments, Nitrososphaera had the highest relative abundance (76.08 to $96.94 \%)$. The relative abundance of Nitrososphaera was significantly higher in CK than that in CS, SS, and AS. However, the relative abundance of Candidatus Nitrosocosmicus was significantly higher in CS, SS, and AS than that in CK. Nitrososphaera (96.94\%) was dominant in CK, and Candidatus Nitrosocosmicus (23.66\%) was significantly enriched in AS (Fig. 6b).

In the amoA-AOB community, Nitrosospira and Nitrosomonas were the two dominant genera (Fig. 6c). Across all treatments, including $\mathrm{CK}$, the relative abundance of Nitrosospira was between 42.41 and $99.04 \%$ and that of Nitrosomonas between 0.01 and $57.53 \%$. The relative abundance of Nitrosospira was significantly higher in CK than that in CS, SS, and AS. However, the relative abundance of Nitrosomonas was significantly higher in CS, SS, and AS than that in CK. Nitrosospira (99.04\%) was dominant in CK, and Nitrosomonas (57.53\%) was significantly enriched in SS (Fig. 6d).

The genotypes of denitrifying communities were significantly affected by saline and alkaline stresses (Fig. 7). Figure $7 \mathrm{a}$ shows the composition of the nirK-type denitrifier communities. The dominant genera included Sinorhizobium and Rhizobium, which together accounted for 40.10 to $59.81 \%$ of the relative abundance in all treatments. The highest relative abundance of Sinorhizobium was in CK, with the relative abundance 89.80\% higher than that in CS, $25.57 \%$ higher than that in SS, and $148.92 \%$ higher than that in AS. However, the lowest relative abundance of Rhizobium was also observed in CK, with the relative abundance $75.22 \%$ lower than that in CS, $82.89 \%$ lower than that in SS, and

Table 4 Diversity indices of amoA-AOA, amoA-AOB, nirk, nirS, and nos Z communities under different salt and alkali stresses in a calcareous desert soil

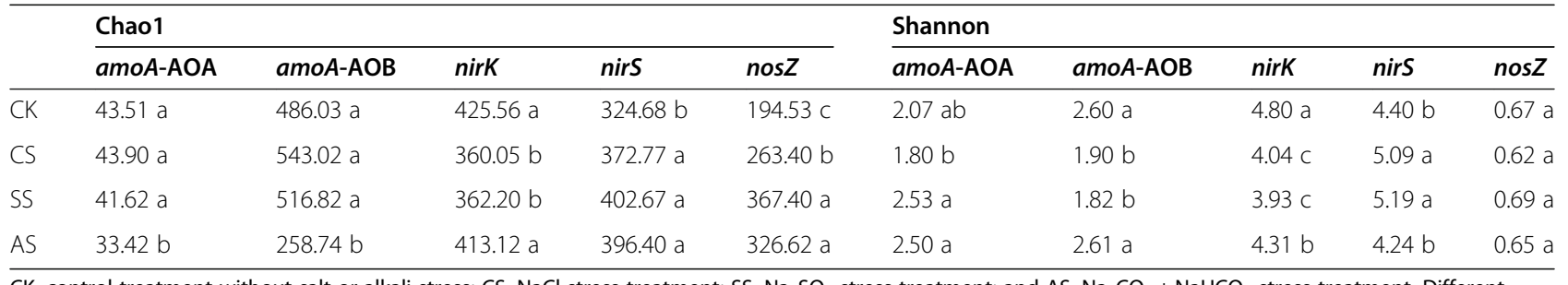

$\mathrm{CK}$, control treatment without salt or alkali stress; $\mathrm{CS}, \mathrm{NaCl}$ stress treatment; $\mathrm{SS}, \mathrm{Na}_{2} \mathrm{SO}_{4}$ stress treatment; and $\mathrm{AS}_{1} \mathrm{Na}_{2} \mathrm{CO}_{3}+\mathrm{NaHCO}_{3}$ stress treatment. Different lowercase letters in the same column indicate significant differences among treatments $(P<0.05)$ 


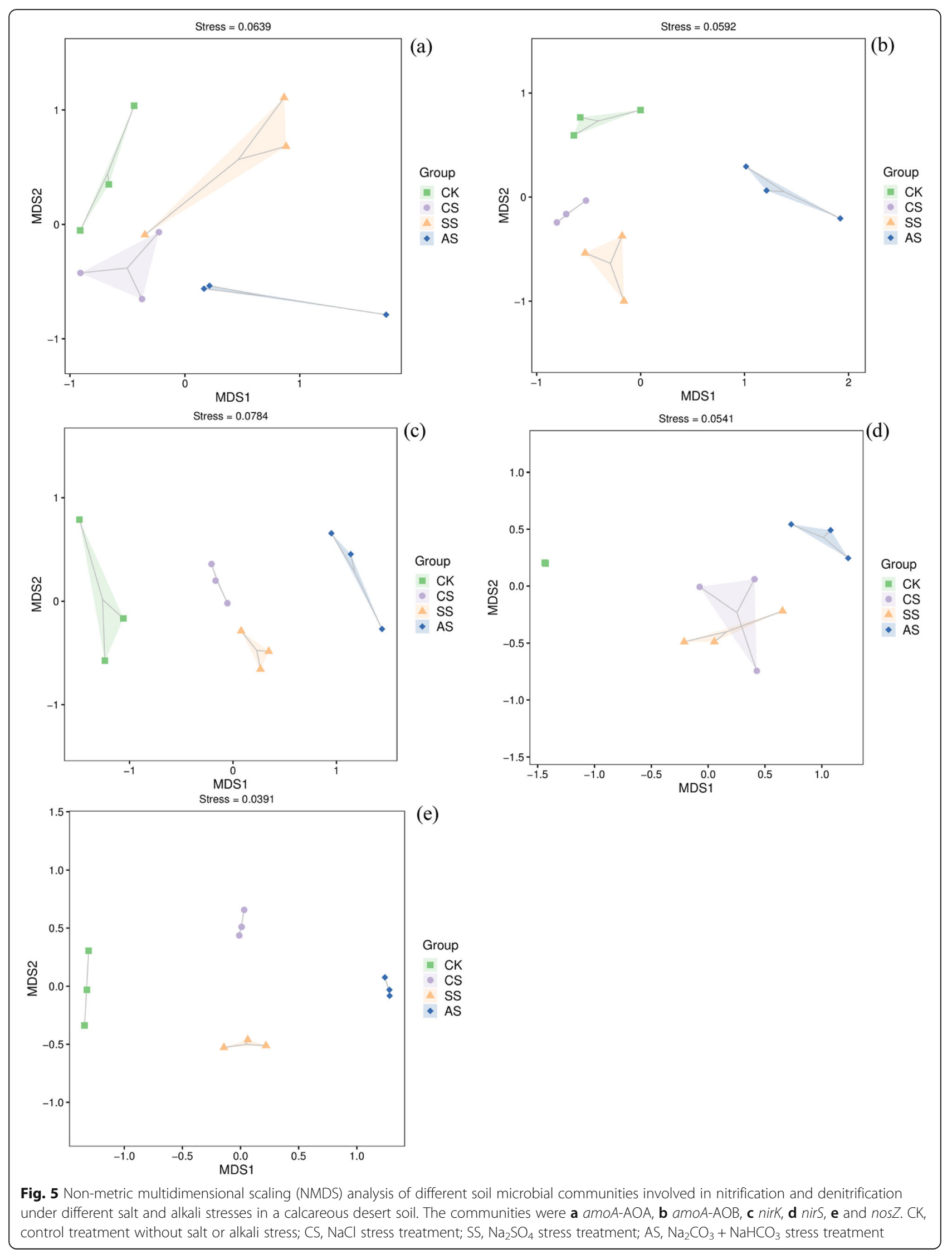




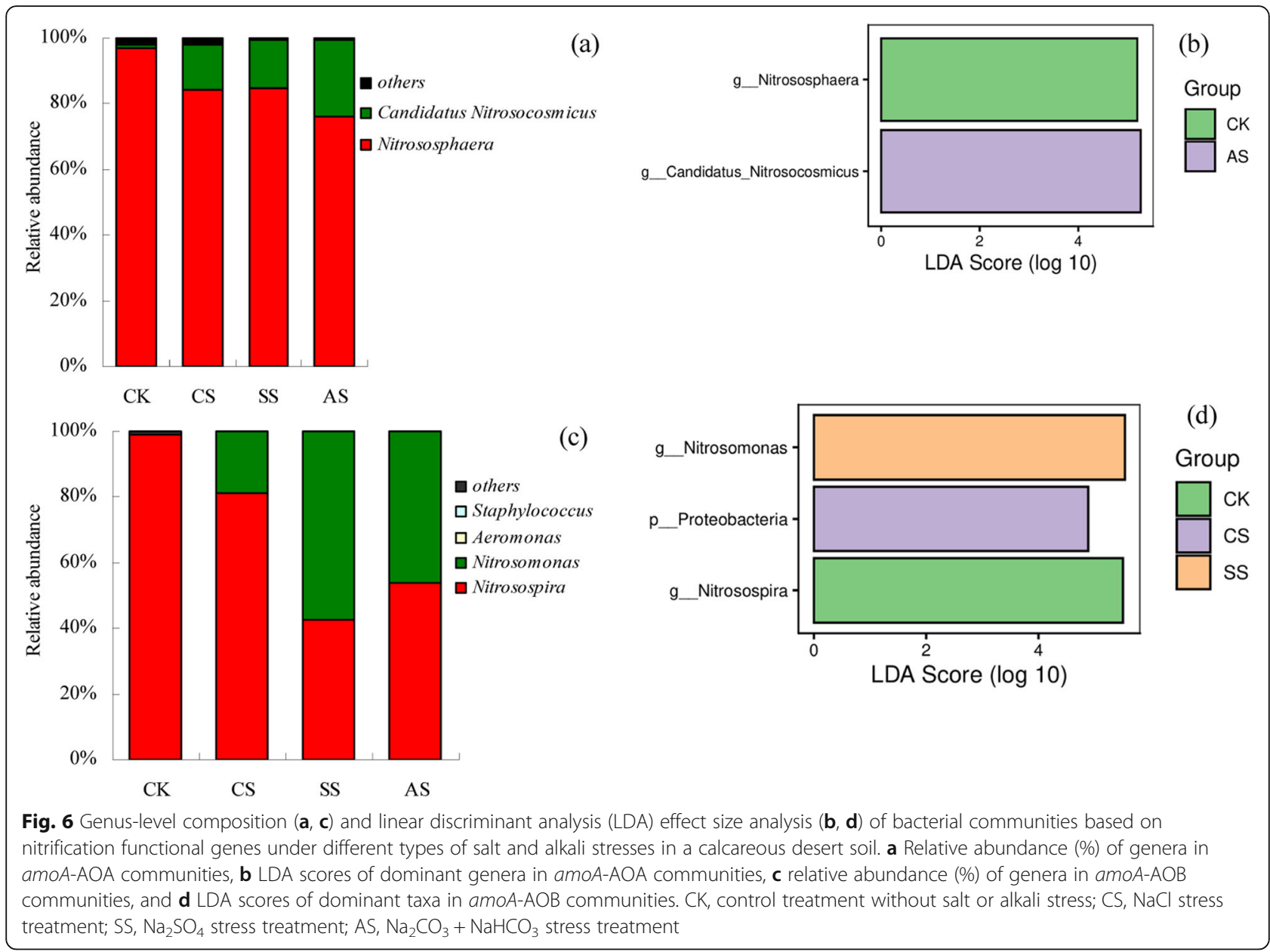

87.01\% lower than that in AS. The other genera in the nirK-type denitrifier communities included Azospirillum (0.40 to 6.96\%), Brucella (0.12 to 3.13\%), Bradyrhizobium (0.56 to $1.83 \%$ ), Bosea (0.19 to $1.81 \%$ ), Paracoccus (1.03 to 3.81\%), Mesorhizobium (0.04 to 0.74\%), Rhodopseudomonas (0.37 to $2.52 \%)$, Devosia (0.01 to $0.77 \%$ ), Agrobacterium (0.01 to $0.30 \%)$, Sagittula (0.04 to 17.73\%), Achromobacter (0.01 to 2.89\%), Pleomorphomonas $(0.00$ to $0.14 \%)$, and Lysobacter(0.00 to $0.01 \%)$. In addition, the relative abundance of Azospirillum and Brucella in CK was significantly higher than that in CS, SS, and AS. Dominant nirK-type denitrifier genera appeared only in AS (Fig. 7b), and the relative abundances of Sagittula (17.73\%), Achromobacter (2.89\%), and Pseudomonas $(0.14 \%)$ were significantly higher than those in other treatments.

In the nirS-type communities, the dominant genera included Azospira, Cupriavidus, Azoarcus, and Pseudomonas (Fig. 7c). The four genera accounted for 26.34 to $56.09 \%$ of the total relative abundance in all treatments. The composition of nirS-type communities varied significantly among the saline and alkaline stress treatments. Compared with $\mathrm{CK}$, the relative abundance of
Azospira decreased significantly 24.02 to $1.71 \%$ and that of Cupriavidus 13.95 to $4.24 \%$ under saline and alkaline stresses. By contrast, the relative abundance of Azoarcus increased significantly 8.80 to $21.60 \%$ under saline and alkaline stresses. Compared with CK, the relative abundance of Pseudomonas increased significantly in CS and SS; however, there was no significant difference between AS and CK. The other genera in the nirS-type communities included Rhodanobacter (0.11 to $1.22 \%)$, Azospirillum (0.21 to $0.98 \%)$, Pseudogulbenkiania (0.18 to $0.78 \%$ ), Thauera (0.57 to $2.71 \%)$, Zoogloea (0.51 to $5.85 \%$ ), Herbaspirillum (0.47 to $1.68 \%$ ), Aromatoleum (0.15 to $1.34 \%$ ), Paracoccus (0.03 to $1.65 \%$ ), Sulfuritalea (0.01 to $0.73 \%$ ), Bradyrhizobium (0.08 to 0.23\%), and Magnetospirillum (0.00 to $1.62 \%)$. Figure $7 \mathrm{~d}$ shows the dominant nirS-type denitrifier taxa. The dominant genera in CK were Azospira (24.02\%), Cupriavidus (13.95\%), Azospirillum (0.98\%), Rhodanobacter (1.22\%), and Pseudogulbenkiania (0.78\%). In CS, the dominant genera were Sulfuritalea (0.73\%) and Magnetospirillum (1.62\%). In SS, Pseudomonas (25.43\%), Thauera (2.71\%), and Aromatoleum (1.34\%) were the dominant genera, and in AS, Zoogloea (5.85\%) and Paracoccus $(1.65 \%)$ were dominant. 


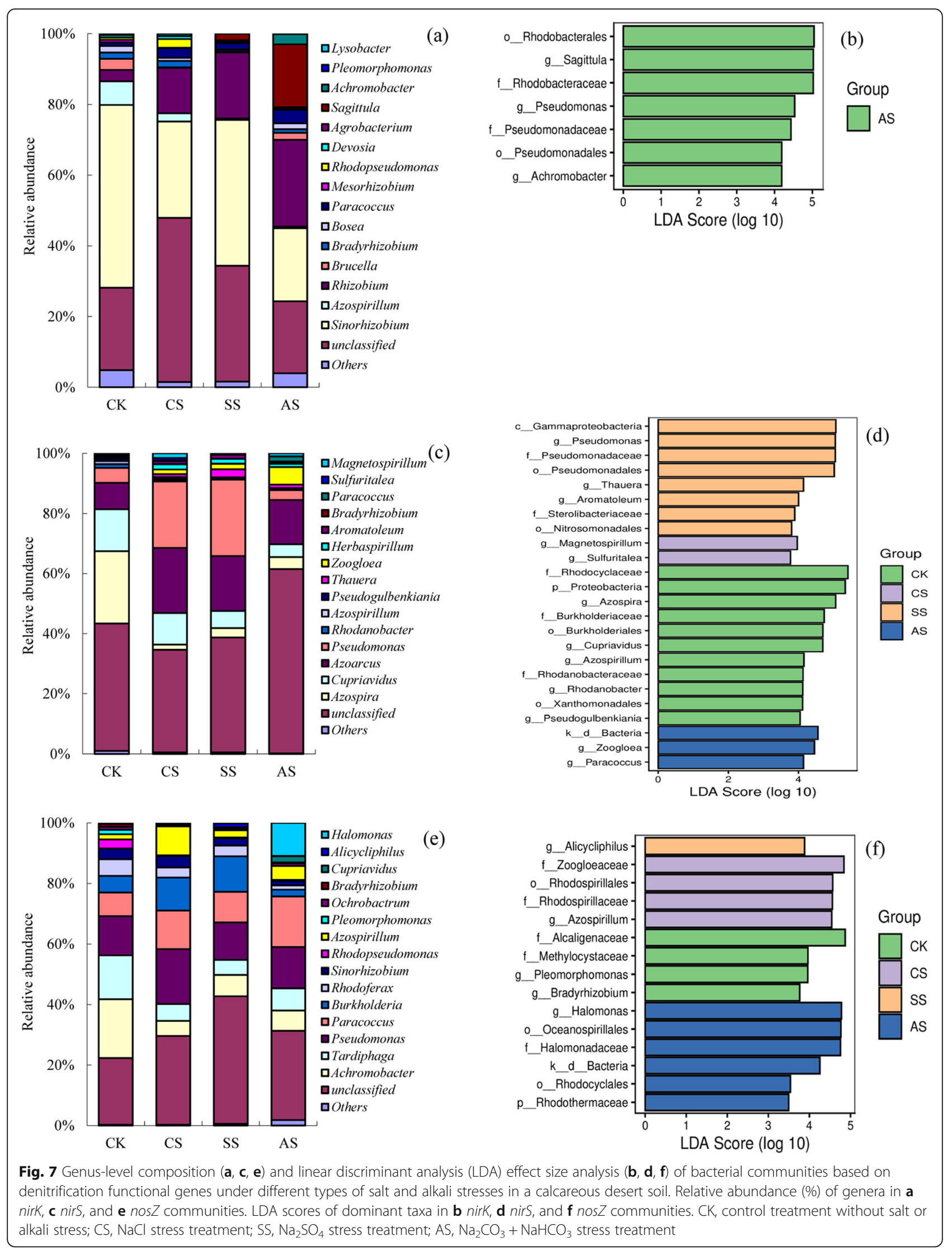


In the nosZ-type communities, the dominant genera included Achromobacter, Tardiphaga, Pseudomonas, Paracoccus, and Burkholderia (Fig. 7e). The five genera accounted for 46.31 to $60.18 \%$ of the total relative abundance in all treatments, with the relative abundance of all $>1 \%$. The relative abundances of Achromobacter and Tardiphaga were higher in CK than in CS, SS, and AS. However, the relative abundance of Paracoccus was lower in CK than in CS, SS, and AS. In CS and SS, the relative abundance of Burkholderia was significantly higher than that in $\mathrm{CK}$ and AS, with the lowest relative abundance in AS. However, the relative abundance of Pseudomonas was not significantly different among the four treatments. The other genera in nosZ-type communities included Rhodoferax (1.40 to 5.51\%), Sinorhizobium (1.54 to 3.83\%), Rhodopseudomonas (0.19 to 2.93\%), Azospirillum (1.72 to 9.50\%), Pleomorphomonas (0.00 to $1.44 \%)$, Ochrobactrum (0.25 to $0.99 \%)$, Bradyrhizobium (0.24 to $0.96 \%)$, Cupriavidus (0.24 to $2.15 \%)$, Halomonas (0.00 to $11.08 \%$ ), and Alicycliphilus (0.00 to $1.22 \%)$, which were in all treatments. By pairwise comparison among different treatments, Pleomorphomonas (1.44\%) and Bradyrhizobium (0.96\%) were dominant in CK, Azospirillum was dominant in CS (9.50\%), Alicycliphilus was dominant in SS (1.22\%), and Halomonas (11.08\%) was dominant in AS (Fig. 7f).

There were some common genera among nirK-type, nirS-type, and nosZ-type denitrifier communities. The genera Achromobacter and Alcaligenes were in both nirK-type and nosZ-type denitrifier communities. The nirK and nos $Z$ genes were found in the genera Aromatoleum, Azoarcus, Cupriavidus, and Herbaspirillum. There were six denitrifiers that had nirK and nos $Z$ genes, including Brucella, Mesorhizobium, Ochrobactrum, Pleomorphomonas, Rhodopseudomonas, and Sinorhizobium.
In addition, all three nirK, nirS, and nos $Z$ genes were identified only in the genera Azospirillum, Bradyrhizobium, Paracoccus, Pseudomonas, and Rhodanobacter.

\section{Redundancy analysis}

Figure 8 shows the correlations between species with amoA-AOA and $a m o A-\mathrm{AOB}$ genes at the genus level and soil properties. Figure $8 \mathrm{a}$ shows the correlation of amoA-AOA community structure with soil properties. Axis 1 and 2 explained $98.44 \%$ of the total variation. The CK samples were clearly separated from those of CS, SS, and AS along axis 1 (98.17\%). However, there was no significant difference between $\mathrm{CS}$ and SS. The amoAAOA community structure was significantly correlated with soil $\mathrm{pH}$ (variation explained, $71.31 \% ; P=0.001$ ), SWC (variation explained, $19.50 \%, P=0.001$ ), and soil salinity (variation explained, $5.40 \%, P=0.003$ ). Nitrososphaera was positively correlated with $\mathrm{NO}_{3}-\mathrm{N}$ and negatively correlated with $\mathrm{pH}$ and $\mathrm{NH}_{4}-\mathrm{N}$, whereas the correlations with Candidatus Nitrosocosmicus were the opposite. For amoA-AOB community structure, axis 1 and axis 2 together explained $95.95 \%$ of the total variation (Fig. 8b). The CK samples were clearly separated from those of CS, SS, and AS along axis 1 (95.42\%). The amoA-AOB community structure was significantly correlated with SWC (variation explained, 35.61\%, $P=$ 0.001 ) and $\mathrm{pH}$ (variation explained, $37.18 \%, P=0.001$ ) but not with the other soil properties. Nitrosospira was positively correlated with $\mathrm{NO}_{3}-\mathrm{N}$ and negatively correlated with $\mathrm{pH}$ and $\mathrm{NH}_{4}-\mathrm{N}$; whereas the correlations with Nitrosomonas were the opposite.

Figure 9 shows the correlations between species with nirK, nirS, and nos $Z$ genes at the genus level and soil properties. Axis 1 and 2 explained $82.19 \%$ of the total variation in the composition of nirK-type denitrifier
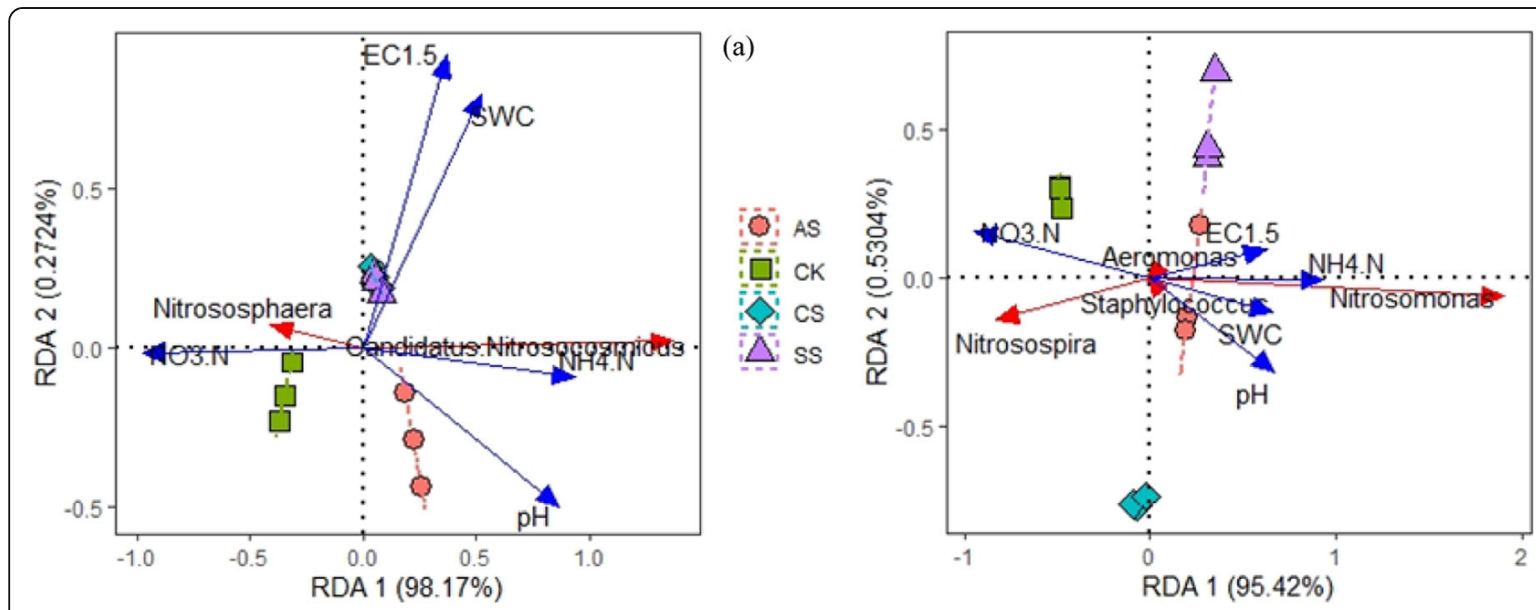

(b)

Fig. 8 Redundancy analyses (RDA) of the correlations between the genera of $\mathbf{a}$ amoA-AOA and $\mathbf{b}$ amoA-AOB communities and soil variables in a calcareous desert soil. CK, control treatment without salt or alkali stress; $\mathrm{CS}, \mathrm{NaCl}$ stress treatment; $\mathrm{SS}_{1} \mathrm{Na}_{2} \mathrm{SO}_{4}$ stress treatment; $\mathrm{AS}_{1} \mathrm{Na}_{2} \mathrm{CO}_{3}+$ $\mathrm{NaHCO}_{3}$ stress treatment 

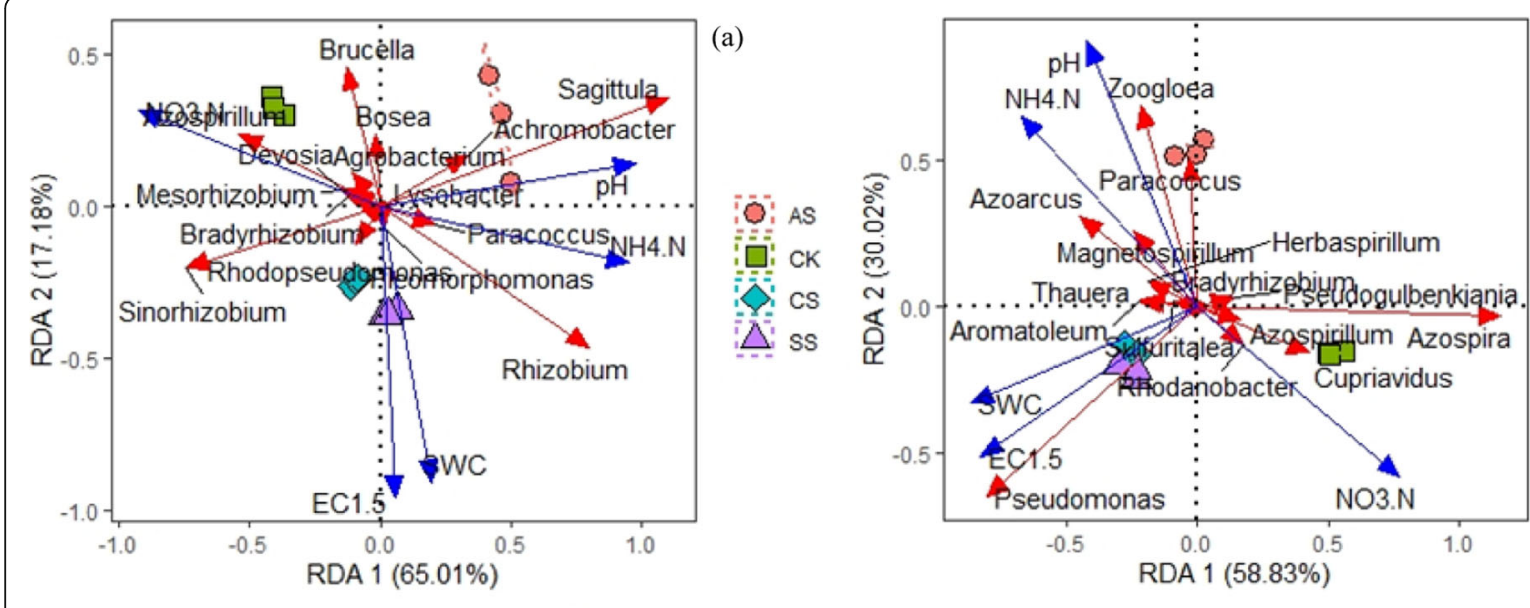

(b)

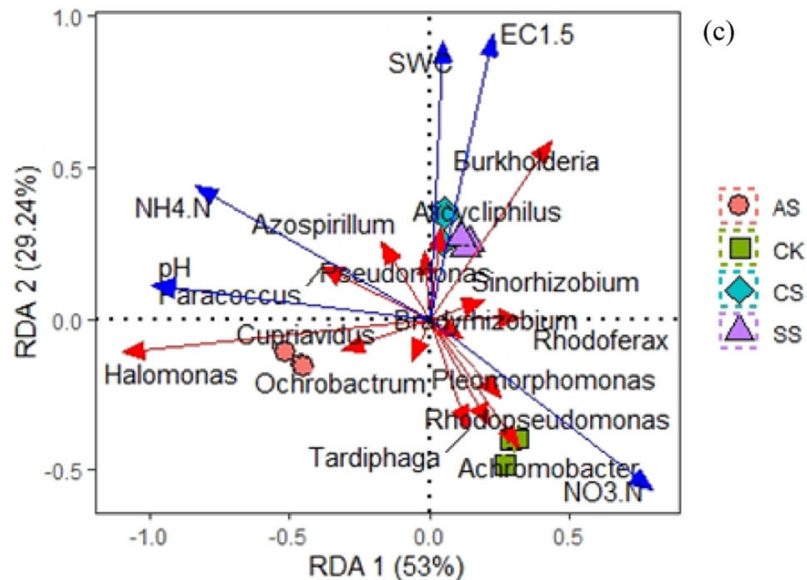

Fig. 9 Redundancy analyses of the correlations between the genera of the denitrifier a nirK, $\mathbf{b}$ nirS, and $\mathbf{c}$ nos $Z$ communities and soil variables in a calcareous desert soil. CK, control treatment without salt or alkali stress; $\mathrm{CS}, \mathrm{NaCl}$ stress treatment; $\mathrm{SS}_{1} \mathrm{Na}_{2} \mathrm{SO}_{4}$ stress treatment; $\mathrm{AS}_{1} \mathrm{Na}_{2} \mathrm{CO}_{3}+$ $\mathrm{NaHCO}_{3}$ stress treatment

communities (Fig. 9a). The nirK-type denitrifier community structure was significantly correlated with $\mathrm{pH}$ (variation explained, 58.61\%, $P=0.001$ ), SWC (variation explained, $8.37 \%, P=0.002$ ), and salinity (variation explained, 7.90\%, $P=0.03$ ). Sinorhizobium, Rhizobium, Sagittula, and Paracoccus were negatively correlated with $\mathrm{pH}$ and $\mathrm{NH}_{4}-\mathrm{N}$ and positively correlated with $\mathrm{NO}_{3}-$ $\mathrm{N}$; whereas the correlations with Azospirillum and Mesorhizobium were the opposite. Bradyrhizobium, Devosia, and Agrobacterium were positively correlated with $\mathrm{NO}_{3}-\mathrm{N}$ and negatively correlated with $\mathrm{NH}_{4}-\mathrm{N}$. Brucella and Bosea were negatively correlated with SWC and salinity. Achromobacter was positively correlated with $\mathrm{NH}_{4}-\mathrm{N}$ and $\mathrm{pH}$. The other genera did not separate and were concentrated at the original point.

For nirS-type denitrifier community structure, axes 1 and 2 explained $88.85 \%$ of the total variation (Fig. 9b). The nirS-type denitrifier community structure was significantly correlated with SWC (variation explained, $41.99 \%, P=0.001$ ), salinity (variation explained, $42.90 \%$, $P=0.009$ ), and $\mathrm{pH}$ (variation explained, $28.49 \%, P=$
0.001), but not with the other soil properties. Cupriavidus, Azospira, Rhodanobacter, and Azospirillum were negatively correlated with $\mathrm{pH}$ and $\mathrm{NH}_{4}-\mathrm{N}$ and positively correlated with $\mathrm{NO}_{3}-\mathrm{N}$, whereas the correlations with Zoogloea and Paracoccus were the opposite. Azoarcus, Pseudomonas, Thauera, Herbaspirillum, and Aromatoleum were positively correlated with SWC and salinity. Pseudogulbenkiania was negatively correlated with SWC, $\mathrm{NH}_{4}-\mathrm{N}$, and salinity and positively correlated with $\mathrm{NO}_{3}-\mathrm{N}$.

Axis 1 and 2 contributed $82.24 \%$ of the total variation in the structure of the nosZ-type denitrifier communities (Fig. 9c). The nosZ-type denitrifier community structure was significantly correlated with soil $\mathrm{pH}$ (variation explained, $47.42 \%, P=0.001$ ), salinity (variation explained, 21.61\%, $P=0.003$ ), and SWC (variation explained, $17.28 \%, P=0.002$ ), but not with the other soil properties. Paracoccus and Halomonas were positively correlated with $\mathrm{pH}$ and $\mathrm{NH}_{4}-\mathrm{N}$ and negatively correlated with $\mathrm{NO}_{3}-\mathrm{N}$, whereas the correlations with Rhodoferax and Sinorhizobium were the opposite. Achromobacter, 
Rhodopseudomonas, and Pleomorphomonas were negatively correlated with SWC, salinity, $\mathrm{pH}$, and $\mathrm{NH}_{4}-\mathrm{N}$ and positively correlated with $\mathrm{NO}_{3}-\mathrm{N}$. Burkholderia and Alicycliphilus were positively correlated with SWC and salinity; whereas the correlations with Ochrobactrum were the opposite. Tardiphaga was negatively correlated with SWC, salinity, and $\mathrm{NH}_{4}-\mathrm{N}$ and positively correlated with $\mathrm{NO}_{3}-\mathrm{N}$. Bradyrhizobium was negatively correlated with SWC, $\mathrm{pH}$, and $\mathrm{NH}_{4}-\mathrm{N}$ and positively correlated with $\mathrm{NO}_{3}-\mathrm{N}$. Cupriavidus was positively correlated with $\mathrm{NH}_{4}$ $\mathrm{N}$ and $\mathrm{NO}_{3}-\mathrm{N}$.

\section{Discussion}

Soil salinization is a worldwide problem and a major challenge to sustaining soil quality. It is an important factors limiting agriculture production in arid regions. Soil salinity mainly causes damage to plants through ion toxicity and osmotic stress, and the inhibition of plant growth is the most common physiological response in a saline and alkaline habitat [35]. In this study, saline and alkaline stresses significantly inhibited cotton growth. The inhibition might have been due to the toxicity of $\mathrm{Na}$ ions with salt stress [36] and the increase in $\mathrm{pH}$ and disturbance of plant nutrition and metabolism with alkaline stress [37]. Salinity adversely affects soil physicochemical properties, which in turn, affect ecosystem nutrient cycling and especially the key transformations of $\mathrm{N}[38,39]$. In this study, $\mathrm{NH}_{4}-\mathrm{N}$ content increased significantly but $\mathrm{NO}_{3}-\mathrm{N}$ content decreased significantly under saline and alkaline stresses (Fig. 1d, e), which might be explained by the inhibition of soil nitrification due to the increase in soil salinity [40]. Saline and alkaline stresses also significantly inhibited soil PNR in this study (Fig. 1f). Akhtara et al. and $\mathrm{He}$ et al. also found that nitrification rates decrease with increases in soil salinity [11, 41]. Thus, these results suggest that saline and alkaline stresses inhibit the conversion of $\mathrm{NH}_{4}-\mathrm{N}$ to $\mathrm{NO}_{3}-\mathrm{N}$, the key microbial process associated with nitrification.

Salinity stress affects soil biological properties by decreasing the abundance and diversity of microbial communities [42]. Moreover, soil salinization is usually accompanied by alkalization, which causes further serious deterioration of soil properties [43]. Microbially mediated soil $\mathrm{N}$ transformations, such as nitrification and denitrification, are also influenced by changes in salinity [44, 45]. Ammonia oxidation is the first and rate-limiting step in nitrification, with $\mathrm{AOB}$ and $\mathrm{AOA}$ the primary microbial groups involved [10]. $\mathrm{Li}$ et al. found that the copies of $a m o A-\mathrm{AOB}$ and $a m o A-\mathrm{AOA}$ are negatively correlated with soil salinity [19]. In this study, saline and alkaline stresses significantly decreased the gene copy numbers of amoA-AOA and amoA-AOB (Fig. 2a, b). This result suggests that the increases in salinity and $\mathrm{pH}$ caused by saline and alkaline stresses are not suitable for the growth and reproduction of $\mathrm{AOB}$ and AOA. However, the gene copies of amoA-AOB were higher than those of $a m o A-A O A$ in this study. One explanation is that $\mathrm{AOB}$ prefer neutral $\mathrm{pH}$ and high- $\mathrm{N}$ agricultural soils, whereas AOA dominate in acidic or low nutrient-content soils [14]. Others have also observed higher abundance of $A O B$ than that of $A O A$ in saline and alkaline soils $[46,47]$ and AOA as the dominant microbial group in acidic soils [48]. Moreover, Nicol et al. reported that amoA-AOB copies decrease with a decrease in soil $\mathrm{pH}$, whereas those of amoA-AOA decrease with an increase in $\mathrm{pH}$ (from 4.9 to 7.5) [9]. $\mathrm{Li}$ et al. reported a $\mathrm{pH}$ range of 5.0 to 7.0 for $\mathrm{AOA}$ enriched from activated sludge, with the optimum $\mathrm{pH}$ at 6.0 [49]. The results collectively suggest that soil $\mathrm{pH}$ has different effects on the ecological sites of $\mathrm{AOB}$ and $\mathrm{AOA}$ under different environmental conditions. In this study, the higher amoA-AOB copy numbers indicated that $\mathrm{AOB}$ was the dominant group in the ammonia-oxidizing community and the major contributor to ammonia oxidation in the saline and alkaline soils. In addition, the copy numbers amoA-AOB and $a m o A-\mathrm{AOA}$ were significantly positively related to soil PNR (Fig. 3), suggesting that $\mathrm{AOB}$ and $\mathrm{AOA}$ participated in nitrification in the saline and alkaline soils. In addition, the amoA-AOA/ amoA-AOB ratio was significantly lower under saline and alkaline stresses than that in the control soil. The decrease in the amoA-AOA/amoA-AOB ratio of the ammonia-oxidizing community indicated there was selective pressure against AOA under saline and alkaline stresses. Collectively, these results support the hypothesis that $\mathrm{AOB}$ are adapted to alkaline to neutral $\mathrm{pH}$ soils, whereas AOA are adapted to acidic soils. Nevertheless, the amoA-AOA/amoA-AOB ratio alone does not provide sufficient information to determine which of the two ammonia-oxidizing groups is functionally dominant in ammonia oxidation [50,51]. The decreases in amo $A$ gene copies might indicate lower potential soil nitrification under the saline and alkaline stresses. Indeed, the copy numbers of amoA-AOB and amoA-AOA amoA in this study were highly related to PNR $(P<0.001$ and $P=0.005$, respectively; Fig. 3 ). The positive linear relations indicated that $a m o A-\mathrm{AOB}$ and $a m o A-\mathrm{AOA}$ were most likely important in explaining the variation in PNR in this soil. However, because the number of $a m o A$ $\mathrm{AOB}$ copies was higher than that of amoA-AOA, the $\mathrm{AOB}$ community might have played a more important role in soil nitrification. Moreover, in correlation analyses, amoA-AOB and amoA-AOA copies were positively correlated with $\mathrm{NO}_{3}-\mathrm{N}$ content (Table 1), further indicating that $\mathrm{AOA}$ and $\mathrm{AOB}$ contributed to nitrification.

The effects of salinity on the structure of $\mathrm{AOB}$ and AOA communities have been investigated in many 
previous studies $[19,20]$. Salinity significantly alters the structure of AOA and AOB communities in wetland soil [52]. In this study, CS decreased the Shannon index of the amoA-AOB community, and AS decreased the Chao 1 index of the amoA-AOA and amoA-AOB communities (Table 3). Dang et al. also found that salinity decreases the diversity of the AOB community [53]. The NMDS analysis (Fig. 5) showed clear separation of communities under saline and alkaline stresses from those in control soil, suggesting that the changes in $a m o A-A O B$ and $a m o A$-AOA communities might be partially attributed to the low concentrations of soil mineral $\mathrm{N}$ and relatively high $\mathrm{pH}$ values associated with saline and alkaline stresses. In addition, in the amoA-AOA communities in this study, the main genera were Nitrososphaera and Candidatus Nitrosocaldus. Saline and alkaline stresses significantly increased the relative abundance of Candidatus Nitrosocaldus, indicating it was strongly tolerant of saline and alkaline stresses. According to Lehtovirta-Morley et al. Candidatus Nitrosocosmicus (AOA), in a Nitrososphaera sister cluster, was first isolated from a near-neutral $\mathrm{pH}$ agricultural soil, suggesting its potential contribution to ammonia oxidation in neutral pH soils [54]. Wu et al. also reported that alkaline soil is suitable for the growth of Candidatus Nitrosotalea (AOA), which shows strong adaptability to $\mathrm{pH}$ variation. In the amoA-AOB communities, the dominant genera were Nitrosospira and Nitrosomonas [55]. Saline and alkaline stresses significantly increased the relative abundance of Nitrosomonas but significantly decreased that of Nitrosospira. By contrast, Sahan and Muyzer found that Nitrosospira is enriched in a high-salt environment, whereas Nitrosomonas is enriched in a low- or mediumsalt environment [56]. According to the Lefse analysis, the dominant genera in CK were Nitrososphaera and Nitrosospira, whereas Nitrosomonas was significantly enriched in SS and Candidatus Nitrosocosmicus was significantly enriched in AS. In this study, the variations in the amoA-AOA community were closely associated with salinity, $\mathrm{SWC}$, and $\mathrm{pH}$, whereas the variations in the amoA-AOB community were only significantly correlated with SWC and $\mathrm{pH}$. Hu et al. also found that the communities of $\mathrm{AOA}$ and $\mathrm{AOB}$ were positively correlated with $\mathrm{pH}$ [57]. Nevertheless, we could not accurately determine the contributions of the amoA-AOA and amoA-AOB communities to nitrification, which need to be investigated further.

Saline and alkaline stresses alter soil physicochemical properties, thereby affecting microbial processes. In this study, the copies of nirK decreased in CS; however, the copies increased significantly in SS and AS. Stress from $\mathrm{NaCl}$ can inhibit denitrification activity [58], and decrease the abundance of denitrifying bacteria [59]. Wang et al. also reported that salinity significantly decreases the abundance of nirK genes [28]. In this study, saline and alkaline stresses significantly increased the copies of nirS and nosZ. Franklin et al. found that the number of denitrifying bacteria also increases with salinity in a beach wetland [60]. One explanation is that saline and alkaline stresses increase soil water content and cause poor soil aeration. Because the nos $Z$ gene is sensitive to oxygen [61], its activity can be inhibited under aerobic conditions [62]. Therefore, with reduced soil aeration after irrigation with saline water, the growth of bacteria with the nos $Z$ genotype may be stimulated [63]. Emissions of $\mathrm{N}_{2} \mathrm{O}$ are inversely related to nos $Z$ gene expression [12]. In addition, an increase in nos $Z$ gene copies indicates that the denitrification process is more complete, leading to $\mathrm{N}_{2}$ as the end product [64]. Moreover, the number of copies of nirK and nos $Z$ was significantly lower than that of nirS. Similarly, Mosier and Francis and Santoro et al. also found that copies of nirS are higher than those of nirK $[65,66]$. Francis et al. found that the nirS gene can increase in richness in low or medium salinity regions, significantly changing community structure and also indicating that nirS is more important in denitrification than nirK or nos $Z$ [60]. In our study, the copies of nirS were positively correlated with $\mathrm{pH}$ and $\mathrm{NH}_{4}-\mathrm{N}$ (Table 1). Morales et al. also found that nirS copies are significantly positively correlated with $\mathrm{NH}_{4}-\mathrm{N}$ content [67]. The copies of nos $\mathrm{Z}$ were positively correlated with $\mathrm{SWC}$ and $\mathrm{EC}_{1: 5}$ (Table 1). The copies of both nirS and nos $Z$ were negatively correlated with $\mathrm{NO}_{3}-\mathrm{N}$; whereas the copies of nirK were not significantly correlated with soil properties. These results indicate that nirS- and nosZ-type denitrifiers are more sensitive than nirK-type denitrifiers to saline and alkaline stresses.

Changes in the copies of denitrifying bacteria under saline and alkaline stresses likely alter community diversity. In this study, CS and SS decreased the Chao1 index of nirK, but saline and alkaline stresses significantly increased that of nirS and nosZ (Table 3). These results suggested that neutral salt (CS and SS) stress reduced the abundance of nirK but AS increased that of nirS and nos $Z$. In addition, saline and alkaline stresses decreased the Shannon index of nirK, whereas CS and SS increased the Shannon index of nirS. These results suggested that saline and alkaline stresses reduced the diversity of nirK but neutral salt (CS and SS) stress increased that of nirS. Thus, saline and alkaline stresses altered the community structure of denitrifying bacteria. The nos $Z$ gene is considered to be relatively stable [68], and in this study, saline and alkaline stresses had no significant effect on its Shannon index. However, this result is in contrast to that of Yang et al. who reported that salinity is positively correlated with the diversity of nos $Z$ genes [69]. The NMDS analysis also showed that saline and alkaline 
stresses significantly altered the community structure of denitrifying bacteria.

In this study, compared with $\mathrm{CK}$, the saline and alkaline stresses altered the community structure of nirK-type denitrifiers. The dominant nirK-type denitrifiers were Sinorhizobium and Rhizobium, similar to the observations by Tang et al. [70]. Saline and alkaline stresses significantly increased the relative abundance of Rhizobium, whereas that of Sinorhizobium significantly decreased, indicating that Rhizobium was strongly tolerant of saline and alkaline stresses. In the nirS-type communities, the dominant genera were Azospira, Cupriavidus, Azoarcus, and Pseudomonas. Saline and alkaline stresses significantly decreased the abundance of Azospira and Cupriavidus, whereas that of Azoarcus significantly increased. In addition, neutral salt (CS and SS) stress significantly increased the relative abundance of Pseudomonas. These results indicated that Azoarcus was strongly tolerant of saline and alkaline stresses and that Pseudomonas was strongly tolerant of neutral salt stress. In the nosZ-type communities, the dominant genera were Achromobacter, Tardiphaga, Pseudomonas, Paracoccus, and Burkholderia. Saline and alkaline stresses significantly decreased the abundance of Achromobacter and Tardiphaga, whereas that of Paracoccus significantly increased. In addition, neutral salt (CS and SS) stress significantly increased the relative abundance of Burkholderia, whereas alkaline stress significantly decreased it. These results indicated that Paracoccus was strongly tolerant of saline and alkaline stresses and that Burkholderia was strongly tolerant of neutral salt stress. Burkholderia also imparts some degree of tolerance in plants to other abiotic stresses such as drought, metal toxicity, and high temperature [71]. The AS treatment had the most potential biomarker species of nirK and nos $Z$ genes, whereas the CS and AS treatments had the fewest potential biomarker species of the nirS gene. The fewest potential biomarkers species of the nos $Z$ gene were in the SS treatment. These results indicated that saline and alkaline stresses affected the structure of different denitrifying bacteria communities to varying degrees. According to RDA, the variations in denitrifier communities were largely explained by salinity, SWC, and $\mathrm{pH}$. Denitrifier community structure is also significantly correlated with salinity, $\mathrm{pH}$, and SWC in previous studies [27, 72].

Farmland soil is the most important source of $\mathrm{N}_{2} \mathrm{O}$ emissions to the atmosphere, and the microbial processes involved in the $\mathrm{N}$ cycle are the primary drivers of those emissions [73]. Henry et al. and Zhao et al. reported that nirS and nirK genes are responsible for the microbial production of $\mathrm{N}_{2} \mathrm{O}$; whereas the nos $\mathrm{Z}$ gene is responsible for reducing $\mathrm{N}_{2} \mathrm{O}$ to $\mathrm{N}_{2}[74,75]$. Thus, the denitrifier communities are critical in regulating $\mathrm{N}_{2} \mathrm{O}$ emissions. Moreover, nitrification may be the main source of $\mathrm{N}_{2} \mathrm{O}$ in arid regions [76] Therefore, soil $\mathrm{N}_{2} \mathrm{O}$ emissions include potential contributions from ammonia-oxidizing bacteria and archaea, which release $\mathrm{N}_{2} \mathrm{O}$ during the nitrification-denitrification process or through links to that process. Thus, the relative contributions of nitrification and denitrification to $\mathrm{N}_{2} \mathrm{O}$ production in saline and alkaline soils should be considered in further research.

\section{Conclusion}

The results of pot experiment support our hypothesis that saline and alkaline stresses changed the abundance and composition of nitrifier and denitrifier community. Saline and alkaline stresses decreased the copy numbers of amoA-AOA and amoA-AOB but increased those of nirS and nosZ, and there were more gene copies of amoA-AOB than of amoA-AOA and more gene copies of nirS than of nirK and nosZ. The PNR was positively linearly related to the copy numbers of both amoA-AOB and $a m o A-A O A$. In addition, saline and alkaline stresses greatly affected the richness, diversity, and structure of nitrifier and denitrifier communities. Saline and alkaline stresses led to increases in the relative abundance of Candidatus Nitrosocosmicus, Nitrosomonas, Rhizobium, Azoarcus, and Paracoccus but decreases in the relative abundance of Nitrososphaera, Nitrosospira, Sinorhizobium, Azospira, Cupriavidus, Achromobacter, Tardiphaga, and Rhodoferax. The $\mathrm{pH}$ and SWC were main drivers of changes in the abundance in amoA-AOA and denitrifier communities, whereas amoA-AOB community structure was only significantly correlated with SWC and pH. Therefore, amoA-AOA and amoA-AOB communities contribute to nitrification in alluvial gray desert soil and that the nirS community may have a more important role in denitrification than nirK and nos $Z$ communities. The present study proposed that a theoretical basis for the efficient use of $\mathrm{N}$ fertilizers and rational $\mathrm{N}$ management in saline or alkaline soils in arid areas.

\section{Methods}

\section{Experimental site and soil description}

Surface soils $(0$ to $30 \mathrm{~cm})$ were collected from a cotton field (Gossypium hirsutum L.) at the experimental station of Shihezi University in Shihezi, Xinjiang Province, China $\left(44^{\circ} 18^{\prime} \mathrm{N}, 86^{\circ} 02^{\prime} \mathrm{E}\right)$. The climate is temperate arid zone with a mean annual temperature of $7.8^{\circ} \mathrm{C}$, precipitation of $210 \mathrm{~mm}$, and evaporation of $1660 \mathrm{~mm}$, with little annual variation. The soil was collected from multiple points in an unfertilized cotton field in March 2019. The soil is classified as calcareous desert soil (Calcaric Fluvisol in the FAO/UNESCO system) with a loam texture. The soil physicochemical properties were 
the following: electric conductivity $\left(\mathrm{EC}_{1: 5}\right), 0.35 \mathrm{dS} \cdot \mathrm{m}^{-1}$; $\mathrm{pH}, 7.86$; organic matter, $14.9 \mathrm{~g} \cdot \mathrm{kg}^{-1}$; alkaline $\mathrm{N}, 41.2$ $\mathrm{mg} \cdot \mathrm{kg}^{-1}$; available P, $10.6 \mathrm{mg} \cdot \mathrm{kg}^{-1}$; and available $\mathrm{K}, 248$ $\mathrm{mg} \cdot \mathrm{kg}^{-1}$.

\section{Experimental design}

A pot experiment was performed in the experiment station greenhouse at Shihezi University. The cotton was planted on 25 April 2020, and seedlings were selected at the two-leaf stage, with four uniform seedlings kept in each pot. The pot experiment was conducted from 25 April 2020 to 10 September 2020. During the experiment, the maximum temperature and minimum temperature of the greenhouse were $15.8^{\circ} \mathrm{C}$ and $41.6^{\circ} \mathrm{C}$, respectively.

According to the salt components and $\mathrm{pH}$ in most of the salt-affected soils in Xinjiang, China, three common types of salt-affected soils were obtained by adding chloride as $\mathrm{NaCl}$ (chloride stress, $\mathrm{CS}$ ), sulfate as $\mathrm{Na}_{2} \mathrm{SO}_{4}$ (sulfate stress, SS), or carbonate as $\mathrm{Na}_{2} \mathrm{CO}_{3}+\mathrm{NaHCO}_{3}$ (alkaline stress, AS) to the sampled soil. The control (CK) soil had no saline or alkaline stress. The soil $\mathrm{EC}_{1: 5}$ and $\mathrm{pH}$ values of the different saline and alkaline stress treatments and their salinization or alkalization degree are shown in Table 5.

The field-collected soil was naturally dried and then crushed and sieved (2-mm pore size). Solutions of $\mathrm{NaCl}$, $\mathrm{Na}_{2} \mathrm{SO}_{4}$, or $\mathrm{Na}_{2} \mathrm{CO}_{3}+\mathrm{NaHCO}_{3}$ (weight ratio 1:1) were added to the soil to produce a supersaturated state (the same volume of deionized water was added to the control soil). The $\mathrm{NaCl}, \mathrm{Na}_{2} \mathrm{SO}_{4}, \mathrm{Na}_{2} \mathrm{CO}_{3}+\mathrm{NaHCO}_{3}$ addition amount were $4.0 \mathrm{~g} / \mathrm{kg}, 6.0 \mathrm{~g} / \mathrm{kg}$, and $1.5 \mathrm{~g} / \mathrm{kg}$, respectively. After mixing evenly, the treated soil was left to stand for 1 month to ensure homogeneous distribution of salt. Then, the three treatment soils were naturally dried, crushed, and passed through a 2-mm sieve.

Non-draining soil pots with $35-\mathrm{cm}$ internal diameter and $60-\mathrm{cm}$ height were used. The treated soil was added to a bulk density of $1.25 \mathrm{~g} \cdot \mathrm{cm}^{-3}$, with $60.0 \mathrm{~kg}$ per soil pots. The experiment was a completely randomized block design with three replications per treatment. The pots were drip-irrigated, and the emitters (and columns) were $0.4 \mathrm{~m}$ apart with a discharge rate (pressure compensated) of $2.1 \mathrm{~L} \cdot \mathrm{h}^{-1}$. The drip irrigation pipe was laid flat on the surface of the soil pots, with each soil pot supplied by one emitter fixed at the center at the top of the pot. During the cotton growing season, the pots were irrigated 12 times. The irrigation interval was seven to 10 days, and $52 \mathrm{~L}$ of irrigation water was added per pot. The pots were all irrigated on the same dates. A flow meter was used to measure the amount of water applied.

The same amount of $\mathrm{N}\left(1,350 \mathrm{~kg} \mathrm{ha}^{-1}, 13.73 \mathrm{~g}\right.$ per pot), $\mathrm{P}_{2} \mathrm{O}_{5}$ (105 $\mathrm{kg} \mathrm{ha}^{-1}, 1.07 \mathrm{~g}$ per pot), and $\mathrm{K}_{2} \mathrm{O}(60 \mathrm{~kg}$ $\mathrm{ha}^{-1}, 0.61 \mathrm{~g}$ per pot) was applied in all treatments. The $\mathrm{N}$ fertilizer was applied through the drip irrigation system during the cotton growing season. Consistent with local practices, urea was the $\mathrm{N}$ source. The $\mathrm{N}$ fertilizer was applied in six equal amounts 53, 64, 72, 81, 90, and 99 days after planting. All pots were fertilized with $\mathrm{P}_{2} \mathrm{O}_{5}$ and $\mathrm{K}_{2} \mathrm{O}$ before sowing.

\section{Cotton sampling}

To determine the dry matter of cotton, three representative cotton plants were selected in each treatment on 5 August 2020 (103 days after planting). The roots, stems, and leaves was washed with distilled water and then dried in an oven at $70{ }^{\circ} \mathrm{C}$ for $48 \mathrm{~h}$, weighed.

\section{Soil sampling}

Soil samples were collected from the 0 to $20 \mathrm{~cm}$ layer from three pots per treatment on 5 August 2020 (103 days after planting). The samples were stored with ice packs and transported to the laboratory. Soils were passed through a 2-mm sieve, after which each soil sample was divided into three subsamples. One subsample was immediately flash-frozen in liquid nitrogen and stored at $-80^{\circ} \mathrm{C}$ for total DNA extraction. One subsample was stored immediately at $4{ }^{\circ} \mathrm{C}$ to determine soil water content (SWC), soil mineral $\mathrm{N}$ content, and potential nitrification rate (PNR). The remaining subsample was air-dried to determine soil salinity and $\mathrm{pH}$.

\section{Soil analyses}

Soil water content was determined gravimetrically by oven drying at $105^{\circ} \mathrm{C}$ until constant weight. Soil $\mathrm{NH}_{4}-\mathrm{N}$ and $\mathrm{NO}_{3}-\mathrm{N}$ were extracted with $2 \mathrm{~mol} \mathrm{~L}^{-1} \mathrm{KCl}(5 \mathrm{~g}$ of soil in $50 \mathrm{~mL}$ of $\mathrm{KCl}$ solution) on a horizontal shaker for $1 \mathrm{~h}$ at $220 \mathrm{rpm}$ and then measured by a Smart Chem140 auto discrete Analyzer (Westco Scientific, Danbury, Connecticut, USA). Soil salinity and $\mathrm{pH}$ were determined with an MP521 lab pH/conductivity meter in a soil: water ratio of $1: 5$ and $1: 2.5$, respectively. As an

Table 5 Soil $\mathrm{EC}_{1: 5,}, \mathrm{pH}$ values, and $\mathrm{Na}^{+}$concentration in different saline and alkaline stress treatments in a calcareous desert soil

\begin{tabular}{lllll}
\hline Treatment & Salinity and alkalinity & $\left.\mathbf{E C}_{\mathbf{1 : 5}} \mathbf{( d S} \cdot \mathbf{m}^{\mathbf{- 1}}\right)$ & $\mathbf{p H}(\mathbf{1 : 2 . 5})$ & $\mathbf{N a}^{+}$concentration $\left.\mathbf{( g} / \mathbf{k g}\right)$ \\
\hline Control (CK) & No additional salinization or alkalization & 0.35 & 8.16 & 0.060 \\
$\mathrm{NaCl}(\mathrm{CS})$ & Moderate salinization & 1.39 & 8.43 & 0.886 \\
$\mathrm{Na}_{2} \mathrm{SO}_{4}$ (SS) & Moderate salinization & 2.01 & 8.19 & 0.827 \\
$\mathrm{Na}_{2} \mathrm{CO}_{3}+\mathrm{NaHCO}_{3}$ (AS) & Moderate alkalization & 0.63 & 9.92 & 0.466 \\
\hline
\end{tabular}


index of the size of active nitrifier populations, soil potential nitrification rate (PNR) was determined using the method described by Kurola et al. [77]. In brief, $5 \mathrm{~g}$ of fresh soil was put into $50 \mathrm{~mL}$ centrifuge tubes containing $20 \mathrm{~mL}$ of phosphate buffer saline solution with $1 \mathrm{mmol}$ $\mathrm{L}^{-1}\left(\mathrm{NH}_{4}\right)_{2} \mathrm{SO}_{4}$. To inhibit nitrite oxidation, potassium chlorate $\left(\mathrm{KClO}_{3}\right)$ was added to the tubes at a final concentration of $10 \mathrm{mmol} \mathrm{L}^{-1}$. After incubation for $24 \mathrm{~h}$ in the dark at the room temperature of $25^{\circ} \mathrm{C}$, nitrite $\left(\mathrm{NO}_{2}\right.$ N) was extracted with $5 \mathrm{~mL}$ of $2 \mathrm{M} \mathrm{KCl}$ and determined spectrophotometrically at $545 \mathrm{~nm}$ with $\mathrm{N}$-(1-naphthyl) ethylenediamine dihydrochloride.

\section{DNA extraction, qPCR assay, and pyrosequencing}

Soil microbial DNA was extracted using a Power Soil ${ }^{\mathrm{mi}}$ DNA Isolation Kit (Mo Bio Laboratories Inc., USA) following the manufacturer's instructions and then stored at $-80^{\circ} \mathrm{C}$. The DNA concentration and purity were measured using a UV-vis spectrophotometer (Thermo Fisher Scientific, Waltham, MA, USA) and agarose gel electrophoresis, respectively. After which, the DNA was stored at $-20^{\circ} \mathrm{C}$.

The abundances of amoA-AOA, amoA-AOB, nirk, nirS, and nos $Z$ were determined by real-time qPCR. Shanghai Personal Biotechnology Co., Ltd. (Shanghai, China) performed the qPCR on a CFX96 Optical RealTime Detection System (Bio-Rad Laboratories, USA). Target plasmids were constructed with PMD-18 plasmids (TaKaRa, Tokyo, Japan), and the correct gene inserts were chosen. The qPCR reaction was performed in triplicate in a $20-\mu \mathrm{L}$ reaction system containing $10 \mu \mathrm{L}$ of $2 \times$ SYBR Green qPCR Master Mix (Applied Biosystems, Foster City, CA, USA), $2 \mu \mathrm{L}$ of DNA template, $1 \mu \mathrm{L}$ of each primer, and $6 \mu \mathrm{L}$ of $\mathrm{ddH}_{2} \mathrm{O}$. After qPCR, the gene copy numbers of nitrification and denitrification genes were normalized by the amount of soil based on the dilution rates and the volumes of the DNA used in the qPCR. Table 6 lists detailed conditions for PCR amplification. The numbers of copies of the target genes were calculated from standard curves.

High-throughput sequencing was used to analyze the composition and diversity of amoA-AOA, amoA-AOB, nirK, nirS, and nos $Z$ gene-based bacterial communities. The primers were the same as those used in the qPCR. The $25-\mu \mathrm{L}$ reaction system included $2 \mu \mathrm{L}$ of DNA template, $1 \mu \mathrm{L}$ of forward and reverse primer $(10 \mu \mathrm{M}), 5 \mu \mathrm{L}$ of $5 \times$ Q5 reaction buffer, $5 \mu \mathrm{L}$ of $5 \times$ Q5 High-Fidelity GC buffer, $0.25 \mu \mathrm{L}$ of Q5 High-Fidelity DNA Polymerase $\left(5 \mathrm{U} \mu \mathrm{L}^{-1}\right), 2 \mu \mathrm{L}$ of $(2.5 \mathrm{mM}) \mathrm{dNTPs}$, and $8.75 \mu \mathrm{L}$ of $\mathrm{ddH}_{2} \mathrm{O}$. The thermal cycle reaction system for the genes used the following program: initial denaturation at $98^{\circ} \mathrm{C}$ for $5 \mathrm{~min}$; 35 cycles consisting of denaturation at $98^{\circ} \mathrm{C}$ for $30 \mathrm{~s}$, annealing at $55^{\circ} \mathrm{C}$ for $30 \mathrm{~s}$, and elongation at $72{ }^{\circ} \mathrm{C}$ for $45 \mathrm{~s}$; and a final extension at $72{ }^{\circ} \mathrm{C}$ for $5 \mathrm{~min}$. The PCR primers were purified with Agencourt AMPure Beads (Beckman Coulter, Indianapolis, IN, USA) and quantified using a PicoGreen dsDNA Assay Kit (Invitrogen, Carlsbad, CA, USA) according to the manufacturer's instructions. After the individual quantification step, equivalent amounts of samples were mixed before high-throughput sequencing was performed using the Illumina MiSeq platform with MiSeq Reagent Kit v3 at Shanghai Aqu Biotechnology Co., Ltd. (Shanghai, China).

\section{Data analyses}

All data are expressed as the mean \pm standard deviation. One-way ANOVA was conducted using SPSS (IBM Software, Chicago, IL, USA). Tukey's test was used to identify significant differences among means $(P<0.05)$. Pearson's correlation analysis was used to test the correlations between PNR, abundance of genes, and soil properties. The sequence data were analyzed using QIIME (version 1.8.0) and $\mathrm{R}$ packages ( $\mathrm{v}$ 3.5.0). The diversity and richness indices were calculated using an operational taxonomic unit (OTU) table in QIIME, the

Table 6 Primers and thermal profiles used for real-time quantitative PCR of the different nitrifying and denitrifying genes in bacterial communities in a calcareous desert soil

\begin{tabular}{|c|c|c|c|c|}
\hline Target gene & Primer & Sequence $\left(5^{\prime}-3^{\prime}\right)$ & Thermal profile & References \\
\hline \multirow[t]{2}{*}{ amoA-AOA } & Arch-amoAF & 5'-STAATGGTCTGGCTTAGACG-3' & \multirow{2}{*}{$\begin{array}{l}95^{\circ} \mathrm{C} \text { for } 5 \mathrm{~min} ; 40 \text { cycles of } 95^{\circ} \mathrm{C} \text { for } 10 \mathrm{~s}, 55^{\circ} \mathrm{C} \text { for } 20 \mathrm{~s} \text {, } \\
\text { and } 72^{\circ} \mathrm{C} \text { for } 30 \mathrm{~s} \text {. }\end{array}$} & \multirow[t]{2}{*}{ Hu et al. [78] } \\
\hline & Arch-amoAR & 5'-GCGGCCATCCATCTGTATGT-3' & & \\
\hline \multirow[t]{2}{*}{ amoA-AOB } & amoA-1F & 5'-GGGGTTTCTACTGGTGGT-3' & \multirow{2}{*}{$\begin{array}{l}95^{\circ} \mathrm{C} \text { for } 5 \mathrm{~min} ; 40 \text { cycles of } 95^{\circ} \mathrm{C} \text { for } 10 \mathrm{~s}, 55^{\circ} \mathrm{C} \text { for } 20 \mathrm{~s} \text {, } \\
\text { and } 72^{\circ} \mathrm{C} \text { for } 30 \mathrm{~s} \text {. }\end{array}$} & \multirow[t]{2}{*}{ Ebie et al. [79] } \\
\hline & amoA-2R & 5'- CCCCTCKGSAAAGCCTTCTTC - 3' & & \\
\hline \multirow[t]{2}{*}{ nirk } & $\mathrm{F} 1 \mathrm{aCu}$ & 5'-ATCATGGTSCTGCCGCG-3' & \multirow{2}{*}{$\begin{array}{l}95^{\circ} \mathrm{C} 2 \text { min, } 1 \text { cycle; } 95^{\circ} \mathrm{C} 20 \mathrm{~s}, 63^{\circ} \mathrm{C} 30 \mathrm{~s}, 72^{\circ} \mathrm{C} 30 \mathrm{~s}, \\
85^{\circ} \mathrm{C} 10 \mathrm{~s}, 35 \text { cycles. }\end{array}$} & \multirow[t]{2}{*}{ Hallin and Lindgren [80] } \\
\hline & $\mathrm{R} 3 \mathrm{Cu}$ & 5'-GCCTCGATCAGRTTGTGGTT-3' & & \\
\hline \multirow[t]{2}{*}{ nirs } & $\mathrm{cd} 3 \mathrm{aF}$ & 5'-GTSAACGTSAAGGARACSGG-3' & \multirow{2}{*}{$\begin{array}{l}95^{\circ} \mathrm{C} 2 \mathrm{~min}, 1 \text { cycle; } 95^{\circ} \mathrm{C} 45 \mathrm{~s}, 55^{\circ} \mathrm{C} 45 \mathrm{~s}, 72^{\circ} \mathrm{C} 45 \mathrm{~s} \text {, } \\
85^{\circ} \mathrm{C} 20 \mathrm{~s}, 40 \text { cycles. }\end{array}$} & \multirow[t]{2}{*}{ Dong et al. [81] } \\
\hline & R3cd & 5'-GASTTCGGRTGSGTCTTGA-3' & & \\
\hline \multirow[t]{2}{*}{$\operatorname{nos} Z$} & nosZ-1126F & 5'-GGGCTBGGGCCRTTGCA-3' & \multirow{2}{*}{$\begin{array}{l}95^{\circ} \mathrm{C} 2 \text { min, } 1 \text { cycle; } 95^{\circ} \mathrm{C} 20 \mathrm{~s}, 60^{\circ} \mathrm{C} 30 \mathrm{~s}, 72^{\circ} \mathrm{C} 30 \mathrm{~s} \text {, } \\
40 \text { cycles. }\end{array}$} & \multirow[t]{2}{*}{ Wu et al. [82] } \\
\hline & nosZ-1381R & 5'-GAAGCGRTCCTTSGARAACTTG-3' & & \\
\hline
\end{tabular}


sequences were grouped into OTUs using a definition of $95 \%$ similarity. The visualization analysis of classification and abundance results was performed in MEGAN. Nonmetric Multidimensional scaling (NMDS) was also conducted based on genus-level compositional profiles. Constrained ordination by redundancy analysis (RDA) in $\mathrm{R}$ (vegan, $\mathrm{v}$ 3.5.0) was used to elucidate relations between the structure of amoA-AOA, amoA-AOB, nirK, nirS, and nos $Z$ gene-based communities and the soil physicochemical properties measured for each sample. Linear discriminant analysis effect size (LEfSe) was calculated in Visual Genomics to search for statistically different biomarkers between treatments.

\section{Abbreviations}

SWC: Soil water content; EC: Electrical conductivity; PNR: Potential nitrification rate; One-way ANOVA: One-way analysis of variance; OTU: Operational taxonomic unit; RDA: Redundancy analysis; NMDS: Nonmetric multidimensional scaling; LEfSe: Linear discriminant analysis effect size

\section{Acknowledgements}

We thank LetPub (www.letpub.com) for its linguistic assistance and scientific consultation during the preparation of this manuscript.

\section{Authors' contributions}

WM, and HJG conceived and designed this experiment. JXG and YXZ collected samples and performed the study. WM, HJG, JXG, and YXZ participated in the acquisition and analysis of the data. JXG wrote the manuscript. HJG and YXZ participated in the discussion draft of the manuscript. WM revised the manuscript finally. All authors read and approved the final manuscript.

\section{Funding}

This work was supported by the Youth Science and Technology Innovation Research Foundation of Xinjiang Production and Construction Crops, China [2020CB020]. The funding agencies had no role in the study design, sample collection, data collection and analysis, and manuscript preparation.

\section{Availability of data and materials}

All sequences recovered by high-throughput sequencing have been deposited into NCBI Sequence Read Archive (SRA, https://www.ncbi.nlm.nih.gov/ sra). The accession number is PRJNA727758 (http://www.ncbi.nlm.nih.gov/ bioproject/727758), which includes 60 accession items (SAMN 19032946 SAMN19033005)

\section{Declarations}

Ethics approval and consent to participate

Not applicable.

\section{Consent for publication}

Not applicable.

\section{Competing interests}

No potential conflict of interest was reported by the authors.

Received: 4 May 2021 Accepted: 6 September 2021

Published online: 15 September 2021

\section{References}

1. Li N, Zheng H, Cui J, Wang J, Liu H, Sun J, et al. Genome-wide association study and candidate gene analysis of alkalinity tolerance in japonica rice germplasm at the seedling stage. Rice. 2019;12(1):24. https://doi.org/10.11 86/s12284-019-0285-y.

2. Wicke B, Smeets E, Dornburg V, Vashev B, Gaiser T, Turkenburg W, et al. The global technical and economic potential of bioenergy from salt-affected soils. Energy Environ Sci. 2011;4(8):2669-81. https://doi.org/10.1039/C1EE01 $029 \mathrm{H}$.

3. Morton MJ, Awlia M, Al-Tamimi N, Saade S, Pailles Y, Negrão S, et al. Salt stress under the scalpel-dissecting the genetics of salt tolerance. Plant J. 2019;97(1):148-63. https://doi.org/10.1111/tpj.14189.

4. Wu YP, Li YF, Zheng CY, Zhang YF, Sun ZJ. Organic amendment application influence soil organism abundance in saline alkali soil. Eur J Soil Biol. 2013; 54:32-40. https://doi.org/10.1016/j.ejsobi.2012.10.006.

5. Shi DC, Yin $L$. Difference between salt $(\mathrm{NaCl})$ and alkaline $\left(\mathrm{Na}_{2} \mathrm{CO}_{3}\right)$ stresses on Puccinellia tenuiflora (Griseb.) Scribn et Merr. plants. Acta Bot Sin. 1993;35: 144-9.

6. Tejada M, Garcia C, Gonzalez JL, Hernandez MT. Use of organic amendment as a strategy for saline soil remediation: influence on the physical, chemical and biological properties of soil. Soil Biol Biochem. 2006;38(6):1413-21. https://doi.org/10.1016/j.soilbio.2005.10.017.

7. Li C, Lei J, Zhao Y, Xu X, Li S. Effect of saline water irrigation on soil development and plant growth in the Taklimakan Desert highway shelterbelt. Soil Tillage Res. 2015;146:99-107. https://doi.org/10.1016/j.still.2 014.03.013.

8. Henderson SL, Dandie CE, Patten CL, Zebarth BJ, Burton DL, Trevors JT, et al Changes in denitrifier abundance, denitrification gene mRNA levels, nitrous oxide emissions, and denitrification in anoxic soilmicrocosms amended with glucose and plant residues. Appl Environ Microbiol. 2010;76(7):2155-64. https://doi.org/10.1128/AEM.02993-09.

9. Nicol GW, Leininger S, Schleper C, Prosser Jl. The influence of soil pH on the diversity, abundance and transcriptional activity of ammonia oxidizing archaea and bacteria. Environ Microbiol. 2008;10(11):2966-78. https://doi. org/10.1111/j.1462-2920.2008.01701.x.

10. Gleeson DB, Müller C, Banerjee S, Ma W, Siciliano SD, Murphy DV. Response of ammonia oxidizing archaea and bacteria to changing water filled pore space. Soil Biol Biochem. 2010;42(10):1888-91. https://doi.org/10.1016/j. soilbio.2010.06.020.

11. Akhtar M, Hussain F, Ashraf MY, Qureshi TM, Akhter J, Awan AR. Influence of salinity on nitrogen transformations in soil. Commun Soil Sci Plant Anal. 2012;43(12):1674-83. https://doi.org/10.1080/00103624.2 012.681738 .

12. Harter J, Krause HM, Schuettler S, Ruser R, Fromme M, Scholten T, et al. Linking $\mathrm{N}_{2} \mathrm{O}$ emissions from biochar-amended soil to the structure and function of the N-cycling microbial community. ISME J. 2014;8(3):660-74. https://doi.org/10.1038/ismej.2013.160.

13. Cui PY, Fan FL, Yin C, Song AL, Huang PR, Tang YJ, et al. Long-term organic and inorganic fertilization alters temperature sensitivity of $\mathrm{N}_{2} \mathrm{O}$ emissions and associatedmicrobes. Soil Biol Biochem. 2016;93:131-41. https://doi.org/1 0.1016/j.soilbio.2015.11.005

14. Di HJ, Cameron KC, Sherlock RR, Shen JP, He JZ, Winefield CS. Nitrous oxide emissions from grazed grassland as affected by a nitrification inhibitor, dicyandiamide, and relationships with ammonia-oxidizing bacteria and archaea. J Soil Sediments. 2010;10(5):943-54. https://doi.org/10.1007/s11368009-0174-x.

15. He JZ, Shen JP, Zhang LM, ZhuY G, Zheng YM, Xu MG, et al. Quantitative analyses of the abundance and composition of ammonia-oxidizing bacteria and ammonia-oxidizing archaea of a Chinese upland red soil under longterm fertilization practices. Environ Microbiol. 2007:9(9):2364-74. https://doi. org/10.1111/j.1462-2920.2007.01358.x.

16. Lehtovirta-Morley LE, Stoecker K, Vilcinskas A, Prosser JI, Nicol GW. Cultivation of an obligate acidophilic ammonia oxidizer from a nitrifying acid soil. Proc Natl Acad Sci. 2011;108(38):15892-7. https://doi.org/10.1073/ pnas. 1107196108.

17. Jiang $X$, Hou $X$, Zhou $X$, Xin $X$, Wright A, Jia Z. pH regulates key players of nitrification in paddy soils. Soil Biol Biochem. 2015;81:9-16. https://doi.org/1 0.1016/j.soilbio.2014.10.025

18. Shi Y, Liu X, Zhang Q. Effects of combined biochar and organic fertilizer on nitrous oxide fluxes and the related nitrifier and denitrifier communities in a saline-alkali soil. Sci Total Environ. 2019;686:199-211. https://doi.org/10.1016/ j.scitotenv.2019.05.394.

19. Li XR, Xiao YP, Ren WW, Liu ZF, Shi JH, Quan ZX. Abundance and composition of ammonia-oxidizing bacteria and archaea in different types of soil in the Yangtze River estuary. J Zhejiang Univ Sci B. 2012;13(10):769_ 82. https://doi.org/10.1631/jzus.B1200013.

20. Guo H, Ma L, Liang Y, Hou Z, Min W. Response of ammonia-oxidizing Bacteria and Archaea to long-term saline water irrigation in alluvial grey 
desert soils. Sci Rep. 2020;10(1):1-11. https://doi.org/10.1038/s41598-01957402-X.

21. Wang YF, Gu JD. Effects of allylthiourea, salinity, and pH on ammonia/ ammonium-oxidizing prokaryotes in mangrove sediment incubated in laboratory microcosms. Appl Microbiol Biotechnol. 2014;98(7):3257-74. https://doi.org/10.1007/s00253-013-5399-3.

22. Mosier AC, Francis CA. Relative abundance and diversity of ammoniaoxidizing archaea and bacteria in the San Francisco Bay estuary. Environ Microbiol. 2008;10(11):3002-16. https://doi.org/10.1111/j.1462-2920.2008.01 764.x.

23. Azziz G, Monza J, Etchebehere C, Irisarri P. nirS- and nirK-type denitrifier communities are differentially affected by soil type, rice cultivar and water management. Eur J Soil Biol. 2017;78:20-8.

24. Shah SA, Shah Z. Changes in soil microbial characteristics with elevated salinity. Sarhad J Agric. 2011;27:233-44.

25. Li J, Ye W, Wei D, Huu Hao N, Guo W, Qiao Y, et al. System performance and microbial community succession in a partial nitrification biofilm reactor in response to salinity stress. Bioresour Technol. 2018;270:512-8. https://doi. org/10.1016/j.biortech.2018.09.068.

26. Deng YL, Ruan YJ, Zhu SM, Guo XS, Han ZY, Ye ZY, et al. The impact of DO and salinity on microbial community in poly (butylene succinate) denitrification reactors for recirculating aquaculture system wastewater treatment. AMB Express. 2017;7(1):113. https://doi.org/10.1186/s13568-0170412-3.

27. Ma L, Guo H, Min W. Nitrous oxide emission and denitrifier bacteria communities in calcareous soil as affected by drip irrigation with saline water. Appl Soil Ecol. 2019;143:222-35. https://doi.org/10.1016/j.apsoil.2019. 08.001.

28. Wang $H$, Gilbert JA, Zhu Y, Yang X. Salinity is a key factor driving the nitrogen cycling in the mangrove sediment. Sci Total Environ. 2018;631: 1342-9. https://doi.org/10.1016/j.scitotenv.2018.03.102.

29. Franklin RB, Morrissey EM, Morina JC. Changes in abundance and community structure of nitrate-reducing bacteria along a salinity gradient in tidal wetlands. Pedobiologia. 2017;60:21-6. https://doi.org/10.1016/j.pedobi.2 016.12 .002$.

30. Li X, Gao D, Hou L, Liu M. Salinity stress changed the biogeochemical controls on $\mathrm{CH}_{4}$ and $\mathrm{N}_{2} \mathrm{O}$ emissions of estuarine and intertidal sediments. Sci Total Environ. 2019;652:593-601. https://doi.org/10.1016/j.scitotenv.201 8.10.294.

31. Ai C, Liang G, Sun J, He P, Tang S, Yang S, et al. The alleviation of acid soil stress in rice by inorganic or organic ameliorants is associated with changes in soil enzyme activity and microbial community composition. Biol Fertil Soils. 2015;51(4):465-77. https://doi.org/10.1007/s00374-015-0994-3.

32. Bai J, Gao H, Xiao R, Wang J, Huang C. A review of soil nitrogen mineralization as affected by water and salt in coastal wetlands: issues and methods. Clean-Soil, Air, Water. 2012;40(10):1099-105. https://doi.org/10.1 002/clen.201200055.

33. He F, Chen $Q$, Jiang $R$, Chen $X$, Zhang F. Yield and nitrogen balance of greenhouse tomato(Lycopersicum esculentum Mill.) with conventional and site-specific nitrogen management in northern China. Nutr Cycl Agroecosyst. 2007;77(1):1-14. https://doi.org/10.1007/s10705-006-6275-7.

34. Mapanda F, Wuta M, Nyamangara J, Rees RM. Nitrogen leaching and indirect nitrous oxide emissions from fertilized croplands in Zimbabwe. Nutr Cycl Agroecosyst. 2012;94(1):85-96. https://doi.org/10.1007/s10705012-9528-7.

35. Wang N, Qiao W, Liu X, Shi J, Xu Q, Zhou H, et al. Relative contribution of $\mathrm{Na}^{+} / \mathrm{K}^{+}$homeostasis, photochemical efficiency and antioxidant defense system to differential salt tolerance in cotton (Gossypium hirsutum L.) cultivars. Plant Physiol Biochem. 2017;119:121-31. https://doi.org/10.1016/j. plaphy.2017.08.024.

36. Lokhande VH, Nikam TD, Patade VY, Ahire ML, Suprasanna P. Effects of optimal and supra-optimal salinity stress on antioxidative defence, osmolytes and in vitro growth responses in Sesuvium portulacastrum L. Plant Cell, Tissue Organ Culture (PCTOC). 2011;104(1):41-9.

37. Yang C, Chong J, Li C, Kim C, Shi D, Wang D. Osmotic adjustment and ion balance traits of an alkali resistant halophyte Kochia sieversiana during adaptation to salt and alkali conditions. Plant Soil. 2007;294(1-2):263-76. https://doi.org/10.1007/s11104-007-9251-3.

38. Amini S, Ghadiri H, Chen CR, Marschner P. Salt-affected soils, reclamation, carbon dynamics, and biochar: a review. J Soils Sediments. 2016;16(3):93953. https://doi.org/10.1007/s11368-015-1293-1.
39. Ma T, Zeng W, Li Q, Wu J, Huang J. Effects of water, salt and nitrogen stress on sunflower (Helianthus annuus L.) at different growth stages. J Soil Sci Plant Nutr. 2016;16(4):1024-37.

40. Bernhard AE, Bollmann A. Estuarine nitrifiers: new players, patterns and processes. Estuar Coast Shelf Sci. 2010;88(1):1-11. https://doi.org/10.1016/j. ecss.2010.01.023.

41. He H, Zhen Y, Mi T, Fu L, Yu Z. Ammonia-oxidizing Archaea and Bacteria differentially contribute to ammonia oxidation in sediments from adjacent waters of Rushan Bay, China. Front Microbiol. 2018;9:116. https://doi.org/1 0.3389/fmicb.2018.00116.

42. Canfora L, Bacci G, Pinzari F, Lo Papa G, Dazzi C, Benedetti A. Salinity and bacterial diversity: to what extent does the concentration of salt affect the bacterial community in a saline soil? PLoS One. 2014;9(9):e106662. https:// doi.org/10.1371/journal.pone.0106662

43. Rengasamy P. Soil processes affecting crop production in salt-affected soils. Funct Plant Biol. 2010;37(7):613-20. https://doi.org/10.1071/FP09249.

44. Hou L, Zheng Y, Liu M, Gong J, Zhang X, Yin G, et al. Anaerobic ammonium oxidation (anammox) bacterial diversity, abundance, and activity in marsh sediments of the Yangtze estuary. J Geophys Res: Biogeosci. 2013;118(3): 1237-46. https://doi.org/10.1002/jgrg.20108.

45. Deng FY, Hou LJ, Liu M, Zheng YL, Yin GY, Li XF, et al. Dissimilatory nitrate reduction processes and associated contribution to nitrogen removal in sediments of the Yangtze estuary. J Geophys Res : Biogeosci. 2015;120(8): 1521-31. https://doi.org/10.1002/2015JG003007.

46. Magalhães CM, Machado A, Bordalo AA. Temporal variability in the abundance of ammonia-oxidizing bacteria vs. archaea in sandy sediments of the Douro River estuary, Portugal. Aquat Microb Ecol. 2009;56(1):13-23. https://doi.org/10.3354/ame01313.

47. Keshri J, Mishra A, Jha B. Microbial population index and community structure in saline-alkaline soil using gene targeted metagenomics. Microbiol Res. 2013;168(3):165-73. https://doi.org/10.1016/j.micres.2012. 09.005.

48. Zhang LM, Hu HW, Shen JP, He JZ. Ammonia-oxidizing archaea have more important role than ammonia-oxidizing bacteria in ammonia oxidation of strongly acidic soils. ISME J. 2012;6(5):1032-45. https://doi.org/10.1038/ ismej.2011.168.

49. Li Y, Ding K, Wen X, Zhang B, Shen B, Yang Y. A novel ammonia-oxidizing archaeon from wastewater treatment plant: its enrichment, physiological and genomic characteristics. Sci Rep. 2016;6(1):1-11. https://doi.org/10.1038/ srep23747.

50. Jia ZJ, Conrad R. Bacteria rather than archaea dominate microbial ammonia oxidation in an agricultural soil. Environ Microbiol. 2009;11(7):1658-e1671. https://doi.org/10.1111/j.1462-2920.2009.01891.x.

51. Wakelin S, Williams E, O'Sullivan CA, Cameron KC, Di HJ, Cave V, et al. Predicting the efficacy of the nitrification inhibitor dicyandiamide in pastoral soils. Plant Soil. 2004;381(1-2):35-43. https://doi.org/10.1007/s11104-014-21 07-8.

52. He Y, Hu W, Ma D, Lan H, Yang Y, Gao Y. Abundance and diversity of ammonia-oxidizing archaea and bacteria in the rhizosphere soil of three plants in the Ebinur Lake wetland. Can J Microbiol. 2017;63(7):573-82. https://doi.org/10.1139/cjm-2016-0492.

53. Dang H, Li J, Chen R, Wang L, Guo L, Zhang Z, et al. Diversity, abundance, and spatial distribution of sediment ammonia-oxidizing Betaproteobacteria in response to environmental gradients and coastal eutrophication in Jiaozhou Bay, China. Appl Environ Microbiol. 2010;76(14):4691-702. https:// doi.org/10.1128/AEM.02563-09.

54. Lehtovirta-Morley LE, Ross J, Hink L, Weber EB, Gubry-Rangin C, Thion C, et al. Isolation of 'Candidatus Nitrosocosmicus franklandus', a novel ureolytic soil archaeal ammonia oxidiser with tolerance to high ammonia concentration. FEMS Microbiol Ecol. 2016;92(5):1-10. https://doi.org/10.1093/ femsec/fiw057.

55. Wu YJ, Whang LM, Fukushima T, Chang SH. Responses of ammoniaoxidizing archaeal and betaproteobacterial populations to wastewater salinity in a full-scale municipal wastewater treatment plant. J Biosci Bioeng. 2013;115(4):424-32. https://doi.org/10.1016/j.jbiosc.2012.11.005.

56. Sahan E, Muyzer G. Diversity and spatio-temporal distribution of ammoniaoxidizing Archaea and Bacteria in sediments of the Westerschelde estuary. FEMS Microbiol Ecol. 2008;64(2):175-86. https://doi.org/10.1111/j.15746941.2008.00462.x.

57. Hu H, Zhang LM, Yuan C, Zheng Y, Wang J, Chen D, et al. The large-scale distribution of ammonia oxidizers in paddy soils is driven by soil $\mathrm{pH}$, 
geographic distance, and climatic factors. Front Microbiol. 2015;6:938. https://doi.org/10.3389/fmicb.2015.00938.

58. Seo DC, Yu K, Delaune RD. Influence of salinity level on sediment denitrification in a Louisiana estuary receiving diverted Mississippi River water. Arch Agron Soil Sci. 2008;54(3):249-57. https://doi.org/10.1080/03 650340701679075

59. Miao Y, Liao R, Zhang XX, Liu B, Li Y, Wu B, et al. Metagenomic insights into salinity effect on diversity and abundance of denitrifying bacteria and genes in an expanded granular sludge bed reactor treating high-nitrate wastewater. Chem Eng J. 2015;277:116-23. https://doi.org/10.1016/j.cej.2015. 04.125.

60. Francis CA, O'Mullan GD, Cornwell JC, Ward BB. Transitions in nirS-type denitrifier diversity, community composition, and biogeochemical activity along the Chesapeake Bay estuary. Front Microbiol. 2013;4:237. https://doi. org/10.3389/fmicb.2013.00237.

61. Burgin AJ, Groffman PM. Soil $\mathrm{O}_{2}$ controls denitrification rates and $\mathrm{N}_{2} \mathrm{O}$ yield in a riparian wetland. J Geophys Res: Biogeosci. 2012;117(G1). https://doi. org/10.1029/2011JG001799.

62. Philippot L, Mirleau P, Mazurier S, Siblot S, Hartmann A, Lemanceau P, et al. Characterization and transcriptional analysis of Pseudomonas fluorescens denitrifying clusters containing the nar, nir, nor and nos genes. Biochim Biophys Acta (BBA)-Gene Structure Expr. 2001;1517:436-40.

63. Gomes J, Khandeparker R, Bandekar M, Meena RM, Ramaiah N. Quantitative analyses of denitrifying bacterial diversity from a seasonally hypoxic monsoon governed tropical coastal region. Deep-Sea Res II Top Stud Oceanogr. 2018;156:34-43. https://doi.org/10.1016/j.dsr2.2017.12.012.

64. Zhai S, Ji M, Zhao Y, Su X. Shift of bacterial community and denitrification functional genes in biofilm electrode reactor in response to high salinity. Environ Res. 2020;184:109007. https://doi.org/10.1016/j.envres.2019.109007.

65. Mosier AC, Francis CA. Denitrifier abundance and activity across the San Francisco Bay estuary. Environ Microbiol Rep. 2010;2(5):667-76. https://doi. org/10.1111/j.1758-2229.2010.00156.x

66. Santoro $A E$, Boehm AB, Francis CA. Denitrifier community composition along a nitrate and salinity gradient in a coastal aquifer. Appl Environ Microbiol. 2006; 72(3):2102-9. https://doi.org/10.1128/AEM.72.3.2102-2109.2006.

67. Morales SE, Jha N, Saggar S. Impact of urine and the application of the nitrification inhibitor DCD on microbial communities in dairy-grazed pasture soils. Soil Biol Biochem. 2015;88:344-53. https://doi.org/10.1016/.soilbio.201 5.06.009.

68. Jones $\mathrm{CM}$, Hallin S. Ecological and evolutionary factors underlying global and local assembly of denitrifier communities. ISME J. 2010;4(5):633-41. https://doi.org/10.1038/ismej.2009.152.

69. Yang A, Zhang X, Agogué H, Dupuy C, Gong J. Contrasting spatiotemporal patterns and environmental drivers of diversity and community structure of ammonia oxidizers, denitrifiers, and anammox bacteria in sediments of estuarine tidal flats. Ann Microbiol. 2015;65(2):879-90. https://doi.org/10.1 007/s13213-014-0929-5.

70. Tang Y, Zhang X, Li D, Wang H, Chen F, Fu X, et al. Impacts of nitrogen and phosphorus additions on the abundance and community structure of ammonia oxidizers and denitrifying bacteria in Chinese fir plantations. Soil Biol Biochem. 2016;103:284-93. https://doi.org/10.1016/j.soilbio.2016.09.001.

71. Grover M, Ali SZ, Sandhya V, Rasul A, Venkateswarlu B. Role of microorganismsin adaptation of agriculture crops to abiotic stresses. World J Microbiol Biotechnol. 2011;27(5):1231-40. https://doi.org/10.1007/s11274010-0572-7.

72. Tao R, Wakelin SA, Liang Y, Hu B, Chu G. Nitrous oxide emission and denitrifier communities in drip-irrigated calcareous soil as affected by chemical and organic fertilizers. Sci Total Environ. 2018;612:739-49. https:/ doi.org/10.1016/.scitotenv.2017.08.258.

73. Hu HW, Chen D, He JZ. Microbial regulation of terrestrial nitrous oxide formation: understanding the biological pathways for prediction of emission rates. FEMS Microbiol Rev. 2015;39(5):729-49. https://doi.org/10.1 093/femsre/fuv021.

74. Henry S, Bru D, Stres B, Hallet S, Philippot L. Quantitative detection of the nos $Z$ gene, encoding nitrous oxide reductase, and comparison of the abundances of $16 \mathrm{~S}$ rRNA, narG, nirK, and nosZ genes in soils. Appl Environ Microbiol. 2006;72(8):5181-9. https://doi.org/10.1128/AEM.00231-06.

75. Zhao S, Wang Q, Zhou J, Yuan D, Zhu G. Linking abundance and community of microbial $\mathrm{N}_{2} \mathrm{O}$-producers and $\mathrm{N}_{2} \mathrm{O}$-reducers with enzymatic $\mathrm{N}_{2} \mathrm{O}$ production potential in a riparian zone. Sci Total Environ. 2018;642: 1090-9. https://doi.org/10.1016/j.scitotenv.2018.06.110.
76. Hink L, Nicol GW, Prosser Jl. Archaea produce lower yields of $\mathrm{N}_{2} \mathrm{O}$ than bacteria during aerobic ammonia oxidation in soil. Environ Microbiol. 2017; 19(12):4829-37. https://doi.org/10.1111/1462-2920.13282.

77. Kurola J, Salkinoja-Salonen M, Aarnio T, Hultman J, Romantschuk M. Activity, diversity and population size of ammonia-oxidising bacteria in oilcontaminated landfarming soil. FEMS Microbiol Lett. 2005;250(1):33-8. https://doi.org/10.1016/j.femsle.2005.06.057.

78. Hu HW, Zhang LM, Dai Y, Di HJ, He JZ. pH-dependent distribution of soil ammonia oxidizers across a large geographical scale as revealed by highthroughput pyrosequencing. J Soils Sediments. 2013;13(8):1439-49. https:// doi.org/10.1007/s11368-013-0726-y.

79. Ebie Y, Noda N, Miura H, Matsumura M, Tsuneda S, Hirata A, et al. Comparative analysis of genetic diversity and expression of amoA in wastewater treatment processes. Appl Microbiol Biotechnol. 2004;64(5):7404. https://doi.org/10.1007/s00253-004-1558-X.

80. Hallin S, Lindgren PE. PCR detection of genes encoding nitrite reductase in denitrifying bacteria. Appl Environ Microbiol. 1999;65(4):1652-7. https://doi. org/10.1128/AEM.65.4.1652-1657.1999.

81. Dong L, Meng Y, Wang J, Liu Y. Evaluation of droplet digital PCR for characterizing plasmid reference material used for quantifying ammonia oxidizers and denitrifiers. Anal Bioanal Chem. 2014;406(6):1701-12. https:// doi.org/10.1007/s00216-013-7546-1.

82. Wu Y, Li Y, Fu X, Liu X, Shen J, Wang Y, et al. Three-dimensional spatial variability in soil microorganisms of nitrification and denitrification at a rowtransect scale in a tea field. Soil Biol Biochem. 2016;103:452-63. https://doi. org/10.1016/j.soilbio.2016.09.013.

\section{Publisher's Note}

Springer Nature remains neutral with regard to jurisdictional claims in published maps and institutional affiliations.

Ready to submit your research? Choose BMC and benefit from

- fast, convenient online submission

- thorough peer review by experienced researchers in your field

- rapid publication on acceptance

- support for research data, including large and complex data types

- gold Open Access which fosters wider collaboration and increased citations

- maximum visibility for your research: over $100 \mathrm{M}$ website views per year

At BMC, research is always in progress.

Learn more biomedcentral.com/submissions 